\title{
Monitoring drought response and chlorophyll content in Quercus by consumer-grade, near-infrared (NIR) camera: a comparison with reflectance spectroscopy
}

\author{
Sabrina Raddi ${ }^{1}$ (D) Francesca Giannetti ${ }^{1}$ (D) Sofia Martini ${ }^{1}$ (D) Fabio Farinella ${ }^{1}$ (D) \\ Gherardo Chirici $^{1}$ (D) . Andrea Tani ${ }^{1} \cdot$ Alberto Maltoni $^{1}$ (D) $\cdot$ Barbara Mariotti ${ }^{1}$ (D)
}

Received: 14 September 2020 / Accepted: 15 April 2021 / Published online: 11 May 2021

(C) The Author(s) 2021

\begin{abstract}
A user-friendly and affordable broad-band digital Near Infrared (NIR) camera (Canon PowerShot S110 NIR) was compared with a narrow-band reflectance spectrometer (USB2000, Ocean Optics) at leaf scale for monitoring changes in response to drought of three ecologically contrasting Quercus species (Q. robur, Q. pubescens, and $Q$. ilex). We aimed to (a) compare vegetation indices (VIs; that is: NDVI, Normalized Difference Vegetation Index; GNDVI, Green NDVI and NIRv, near-infrared reflectance of vegetation) retrieved by NIRcamera and spectrometer in order to test the reliability of a simple, low-cost, and rapid setup for widespread field applications; (b) to assess if NIR-camera VIs might be used to quantify water stress in oak seedlings; and (c) to track changes in leaf chlorophyll content. The study was carried out during a water stress test on 1-year-old seedlings in a greenhouse. The camera detected plant status in response to drought with results highly comparable to the visible/NIR (VIS/NIR) spectrometer (by calibration and standard geometry). Consistency between VIs and morpho-physiological traits was higher in $Q$. robur, the most drought-sensitive among the three species. Chlorophyll content was estimated with a high goodness-of-fit by VIs or reflectance bands in the visible range. Overall, NDVI performed better than GNDVI and NIRv, and VIs performed better than single bands. Looking forward, NIR-camera VIs are adequate for the early monitoring of drought stress in oak seedlings (or small trees) in the post-planting phase or in nursery settings, thus offering a new, reliable alternative for when costs are crucial, such as in the context of restoration programs.
\end{abstract}

Keywords Forest seedlings $\cdot$ Multispectral NIR-camera $\cdot$ Leaf spectroscopy $\cdot$ Proximal sensing $\cdot$ Water-stress indices $\cdot$ Chlorophyll

Francesca Giannetti

francesca.giannetti@unifi.it

Extended author information available on the last page of the article 


\section{Introduction}

In forestry-where extent, location, and/or terrain morphology hinder the efforts to effectively and extensively monitor plant physiological traits - the application of simple, rapid, and cost-effective digital photographic methods would be advantageous for tracking plant cover (Salas-Aguilar et al. 2017), phenology (Richardson et al. 2018), and physiology (Keenan et al. 2014). These techniques could be especially useful in evaluating afforestation/reforestation or forest restoration project success (Vallauri et al. 2005), and, more generally, for tree seedling quality assessment and phenotyping (do Amaral et al. 2019). In response to stresses, leaf traits change with plant and environmental conditions over a wide range of timescales, involving their biochemical composition, physiology, structure, and economics (growth and shedding; e.g., Osakabe et al. 2014; Choat et al. 2018). Although highly reliable biochemical and ecophysiological protocols remain the state-of-the-art for field assessments of leaf traits, the development of cost-efficient and non-destructive methods that are aimed at monitoring leaf traits at the plant or stand scale is increasingly gaining importance (Cotrozzi et al. 2018; Chawade et al. 2019).

Real-time plant status monitoring would be useful for different forest restoration aspects, such as to quantify seedling status (before and during outplanting phase), in order to adopt time effective management techniques for plant survival and productivity (Cotrozzi et al. 2017; Löf et al. 2019) or to promote more sustainable practices (Reiche et al. 2018; Löf et al. 2019). Other applications concern actions to deal with climate change challenges (Reyer et al. 2013; Trumbore et al. 2015), especially those linked to drought (Zhao and Running 2010; IPCC 2014; Green et al. 2019) and extreme events, such as heatwaves (Hoerling et al. 2012; Schuldt et al. 2020), which begin to hit also regions that currently only experience limited dry periods (Eckstein et al. 2019). Recently, in the framework of water security, nature-based solutions and a more sustainable use of water-resources, it is required to rapidly and carefully detect plant status, in order to become operational in many activities (Harou et al. 2009; Cohen-Shacham et al. 2016), such as nursery (Fulcher et al. 2016; Knight et al. 2019) or precision agriculture and forestry (FAO 2013; Fardusi et al. 2017; Mereu et al. 2018).

Remote sensing (e.g., Iglhaut et al. 2019; Puletti et al. 2019) or leaf spectroscopy (e.g., Colombo et al. 2012; Cotrozzi and Couture 2019; Jacquemoud and Ustin 2019) have great potential to address these tasks (Humplík et al. 2015; Mahlein et al. 2018). Moreover, reliable, fast, and user-friendly monitoring systems at affordable costs would facilitate the spread of breakthrough technology, particularly by remote and "near-surface" sensing techniques (Baresel et al. 2017; Di Gennaro et al. 2018). Recently, near-surface sensing and high pixel resolution imagery allowed the targeting of single plant parts (e.g., leaf, stem or canopy by segmentation techniques, Perez-Sanz et al. 2017; Chianucci et al. 2019). Hyperor multi-spectral sensors provide reasonably high spatial and spectral resolution to infer many structural (leaf area index and canopy cover) and biochemical (nitrogen and chlorophyll content) canopy attributes down to leaf scale.

Chlorophyll content is an important bio-indicator for many physiological processes linked to phenology, photosynthetic capacity (Croft et al. 2017), and stress detection, including drought stress; (Esteban et al. 2015), and—unlike other foliar pigments (Ollinger 2011) — it can be estimated with high accuracy (Homolová et al. 2013). Thus, in the last decades, several approaches have been proposed to estimate chlorophyll content at different spectral (Blackburn 1998) and spatial resolutions (Sonobe and Wang 2017; Croft et al. 2020), also by simple and robust metrics, such as Vegetation Indices (VIs; Alberton et al. 
2017; Yang et al. 2017; Zhang et al. 2019), and user-friendly instruments, such as digital NIR-cameras (e.g., Chung et al. 2018). Unfortunately, prices and technical requirements, such as temperature stability, are presently limiting the widespread use of high-resolution multispectral digital cameras; whereas, more cost-affordable digital multispectral cameras (e.g., Parrot Sequoia or MicaSense UAV cameras) gain field for agricultural and forest monitoring. However, the latter require demanding post-processing efforts in imagery co-registration (e.g., Nebiker et al. 2016), as their multi-optics acquire different parts of the electromagnetic spectrum from different view angles. In this scenario, low-cost (about one-tenth the cost of a multispectral camera), user-friendly and handheld compact NIRcameras, which acquire Green-Red-NIR images (as used in this study) could offer several advantages for their simplicity in use: no co-registration is required (due to their single optic) and after a minimal training effort they would offer several useful applications in environmental management.

In this framework, we aimed to compare at leaf scale an affordable NIR-camera with narrow-band reflectance spectrometer in order to explore its reliability for monitoring reflectance indices and chlorophyll changes in response to drought in Quercus; one of the most important tree genus in the northern hemisphere (Dey et al. 2012). Despite many studies on remote or proximal sensing (e.g., Thenkabail et al. 2019), comparative studies between these two handheld instruments remain, to our knowledge, scarce (Ritchie 2007; Putra and Soni 2017). Our aims were threefold: (a) to compare VIs calculated by the broadband NIR digital-camera with those of the narrow-band spectrometer to test the reliability of a simple and affordable setup for widespread field applications; (b) to assess whether NIR-camera VIs might be used to quantify water stress in oak seedlings; and (c) to track changes in leaf chlorophyll content in response to drought for three important European oak species, characterized by different ecological water needs.

\section{Materials and methods}

\section{Plant material}

The study was carried out in early summer 2018 under semi-controlled conditions in a nursery greenhouse (Pistoia, Italy; 43.862182 N, $10.980419 \mathrm{E} ; 43 \mathrm{~m}$ a.s.1.) during the second growing season of seedlings of three Quercus species: $Q$. robur L., $Q$. pubescens Willd., and $Q$. ilex L. (hereafter, QR, QP, and QI, respectively), and during a concurrent water stress trial (Mariotti et al. 2019). In 2017, seedlings were grown in 0.65 L containers filled with two substrates (Sub: Peat, Pe; Coconut fiber, Co) and three fertilizations (Fert: nursery standard, St; enriched in $\mathrm{K}, \mathrm{K}$; enriched in $\mathrm{P}, \mathrm{P}$ ) resulting in a total of six stocktypes (Sub x Fert; further details in Mariotti et al. 2020). In mid-April 2018, 45 seedlings per stocktype and species (total $=810 ; 15$ seedlings per experimental unit) were transplanted into $3 \mathrm{~L}$ pots filled with coconut fiber substrate (without any further fertilization), placed in a greenhouse, where homogeneity of environmental conditions (i.e. PAR, temperature, and air humidity - data not shown) was checked, and kept well-watered until the on-set of the water stress trial. 


\section{Water stress: experimental setup and morpho-physiological stress indices}

The water stress test lasted two weeks from DOY 178 (T0) to DOY 191 (T1). Seedlings were daily drip-irrigated according to three watering regimes: (1) control $(\mathrm{C})$, where the water delivered to each pot maintained the soil at field capacity (FC, calculated from the daily loss of weight separately for each species); (2) medium water stress (MS), i.e., $50 \%$ of FC; (3) high water stress (HS), where the amount of water was calculated to maintain a species-specific threshold of soil humidity defined as highly stressful according to literature; specifically, Früchtenicht et al. (2018) found a high water stress (i.e., predawn branch water potentials below -2 MPa) with volumetric soil water content (SWC) of 13\%, 9\%, and $6 \%$ in QR, QP, and QI, respectively. SWC was monitored every other day by FieldScout TDR 150 (Spectrum Technologies, USA). For spectrometer and NIR camera measurements, 3 mature leaves per pot on 5 pots per treatment (810 leaves in total) were sampled and marked at $\mathrm{T} 0$ in order to be re-measured at T1. For HS, fearing high leaf mortality and high response variability among seedlings, an additional sample of 10 leaves (1 leaf per pot) was marked. For further evaluating NIR camera VIs indices against plant status we measured predawn leaf water potential $\left(\Psi_{\mathrm{PDL}}\right.$ in MPa; PMS pressure chamber, Co. Corvallis, USA - on one leaf per plant, 4 plants per treatment randomly selected, 216 leaves in total) and early-morning maximum photosynthetic efficiency ( $\mathrm{Fv} / \mathrm{Fm}$, the ratio of variable, Fv, to maximum, Fm, fluorescence after 45 min dark-adaptation; Handy PEA fluorimeter, Hansatech, UK-1 leaf on 9 plants per treatment, 486 in total), along with total plant height $(\mathrm{H})$ growth during the trial calculated as $\mathrm{H}_{\mathrm{T} 1}-\mathrm{H}_{\mathrm{T} 0}$ difference. During midday (11:30 to 14:30) and under clear sky conditions, NIR-camera images and leaf reflectance spectrum were taken in that order (and within a few seconds of one another) on the same leaf acclimated to saturating PAR.

\section{NIR-camera vegetation indices}

A single-chip camera was used to take leaf images (PowerShot S110 NIR, Canon Inc., Tokyo, Japan), as it offered the advantage to co-register each band by a Bayer color filter at the cost of a partial spectral overlap. Green (G), Red (R), and NIR bands were centered at $550 \mathrm{~nm}, 625 \mathrm{~nm}$, and $850 \mathrm{~nm}$, respectively. Images were acquired in RAW mode (maximum resolution, focal length $=32 \mathrm{~mm}$, exposure time $=1 / 125 \mathrm{~s}$, f-value $=5.7$ ) and nadir position (i.e., vertically downward) at a distance of $30 \mathrm{~cm}$ from an attached leaf, avoiding shadows or reflections. A $0.6 \mathrm{~mm}$ thick barium sulfate panel laid next to the leaf served as a white reference (Knighton and Bugbee 2005). Images were processed using the "dcraw" open-source program (Coffin 2018). In Table 1, selected 'dcraw' parameters are reported to capture scene full brightness range at maximum radiometric resolution (16 bit) to preserve the linear dependence of digital numbers (DN) to actual brightness (Chianucci et al. 2019). A segmentation procedure was applied to separate the leaf blade image from the background (Baresel et al. 2017) and leaf reflectance was calculated as $\mathrm{DN}_{\text {leaf, } x}$ ' $\mathrm{DN}_{\text {reference, } x}$, where $x$ was $\mathrm{G}, \mathrm{R}$, and NIR band, respectively, and DN was the mean digital number either over the whole leaf blade or the white reference. The following vegetation indices (VIs) were calculated-namely, normalized difference vegetation index, $\mathrm{NDVI}=(\mathrm{NIR}-\mathrm{Red}) /(\mathrm{NIR}+\mathrm{Red})$, $($ Rouse et al. 1973); green normalized difference vegetation index, GNDVI = (NIR - Green $) /(\mathrm{NIR}+$ Green $)$, (Gitelson et al. 1996), which is also equivalent to minus the normalized difference water index (NDWI, McFeeters 1996) and near-infrared reflectance of vegetation, NIRv $=$ NDVI $\cdot$ NIR (Badgley et al. 2017), an index 
Table 1 Parameter set used for image corrections in "dcraw" software

\begin{tabular}{ll}
\hline Parameter & Set \\
\hline D & $\begin{array}{c}\text { Document made without } \\
\text { rescaling (totally raw) }\end{array}$ \\
W & No automatic brightening \\
G 11 & Custom gamma curve \\
K & Subtract dark frame \\
T & Write 16 bit TIF \\
\hline
\end{tabular}

A complete parameter selection list is provided at http://manpages. ubuntu.com/manpages/xenial/man1/dcraw.1.html\#interpolation\%20opt ions

proposed as a proxy of light-saturated photosynthesis $\left(\mathrm{A}_{\max }\right)$ at leaf scale for deciduous tree species included Quercus (Wong et al. 2020).

\section{Spectrometer vegetation indices}

Leaf reflectance was measured on the upper leaf blade (in the central and wider part, avoiding midrib and major veins). Two nearby positions were measured with a $45^{\circ}$ off-nadir and backscatter mode geometry by a 10 bit VIS/NIR spectrometer (USB2000, Ocean Optics, Orlando, USA; $0.4 \mathrm{~nm}$ nominal resolution; range $=350-1100 \mathrm{~nm})$ connected to a low-OH optical bifurcated fiber (QR200-7-VIS-NIR, OceanOptics; $25^{\circ}$ field of view) and a stabilized (and 45' preheated) light source (LS-1, Ocean Optics). Spectral reflectance $\left(\mathrm{R}_{\mathrm{wl}}\right.$, $\mathrm{wl}=$ wavelength in $\mathrm{nm}$ ) was calculated with respect to a $99 \%$ certified Lambertian white reference (Spectralon White Reference, Labsphere Inc., NH, USA) after electric noise (dark) removal and Savitzky-Golay smoothing (3rd order polynomial on a $20 \mathrm{~nm}$ window). Reflectance was extracted for the three nominal NIR-camera bands in order to calculate narrow-band VIs. Moreover, the red-edge bands at $705 \mathrm{~nm}$ and $750 \mathrm{~nm}$ were used to determine total $(\mathrm{a}+\mathrm{b})$ chlorophyll content $\left(\mathrm{C}_{\mathrm{ab}}, \mu \mathrm{g} \mathrm{cm}{ }^{-2}\right)$ by $\mathrm{ND}_{705}=\left(\mathrm{R}_{750}-\mathrm{R}_{705}\right) /\left(\mathrm{R}_{750}+\mathrm{R}_{705}\right)$ (Gitelson and Merzlyak 1994; Sims and Gamon 2002). The following quadratic equation: $\mathrm{C}_{\mathrm{ab}}\left(\right.$ in $\left.\mu \mathrm{g} \mathrm{cm}^{-2}\right)=0.4936485+50.26586 \cdot \mathrm{ND}_{705}+90.740 \cdot \mathrm{ND}_{705}{ }^{2}\left(\mathrm{R}^{2}=0.96, P<0.0001\right)$ was obtained by extracting $\mathrm{C}_{\mathrm{ab}}$ and $\mathrm{ND}_{705}$ values from Féret et al. (2011) leaf database (there reported under graphical form) by WebPlotDigitalizer v. 4.3 (Rohatgi 2017). Spectrometer reflectance spectra were then classified in $\mathrm{C}_{\mathrm{ab}}$ classes by step of $5 \mu \mathrm{g} \mathrm{cm}^{-2}$. Leaf spectra belonging to the lowest $\left(0-5 \mu \mathrm{g} \mathrm{cm}^{-2}\right) \mathrm{C}_{\mathrm{ab}}$ class (yellowed to brownish leaves) were hereafter referred to as "discolored."

\section{Statistical analyses}

Statistical analyses were carried out in R v. 3.6.1 (R Development Core Team 2020) using the packages "stats" and "dplyr" (Wickham et al. 2021). Reflectance was reported throughout the paper in percent. NIR-camera and spectrometer comparisons were performed for VIs and NIR-camera nominal bands, averaging (mean) values within the leaf. ANOVA and Tukey's honest significant difference (HSD) test were performed within species and stocktype to assess differences at $\alpha=0.05(P \leq 0.05)$ among stress treatments for NIR-camera VIs and morpho-physiological stress indices. In case of ANOVA-assumption rejection, a 
non-parametric Kruskal-Wallis test was applied with differences $(P \leq 0.05)$ assessed by Dunn test with Holm correction.

Spectrometer reflectance $\left(\mathrm{R}_{\mathrm{wl}}\right)$ and normalized indices $\left(\mathrm{VI}_{850, \mathrm{wl}}=\left(\mathrm{R}_{850}-\mathrm{R}_{\mathrm{wl}}\right)\right.$ / $\left(R_{850}+R_{w l}\right)$ were computed with reflectance at $850 \mathrm{~nm}$ as NIR. Over the $400-1000 \mathrm{~nm}$ spectrometer range, correlograms drew adjusted $\mathrm{R}^{2}$ values $v s$ wavelengths for determining the best ranges for $\mathrm{C}_{\mathrm{ab}}$ estimation on the base of reflectance $\left(\mathrm{R}_{\mathrm{wl}}\right)$ or normalized indices $\left(\mathrm{VI}_{850, \mathrm{wl}}\right)$. Here, both linear and non-linear (quadratic and exponential) functions were tested, using single leaf spectra as input.

\section{Results}

\section{Comparison between NIR-camera and spectrometer}

All NIR-camera and spectrometer VIs were very highly $(P \leq 0.001)$ correlated over the whole dataset $\left(\mathrm{R}^{2}>0.89\right.$, number of observations $\left.=1794\right)$; goodness-of-fit was slightly better both for NDVI and NIRv $\left(\mathrm{R}^{2}=0.98\right)$ than for GNDVI $\left(\mathrm{R}^{2}=0.92\right)$. Conversely, Root Mean Squared Error (RMSE) was below 0.01 for NDVI and GNDVI, and larger (2.86) for NIRv. All indices showed a non-significant intercept and homogenous variances between devices (Levene's P, NDVI, $\mathrm{P}=0.88$; NIRv, $P=0.67$; GNDVI; $P=0.18$ ). The two devices also showed non-normal distribution (Shapiro $P \leq 0.001$ ), and similar median and min-max ranges for all the three indices (data not shown), despite GNDVI being spread over a lower range. The two instruments were also highly correlated $(P \leq 0.001)$ for all indices both within date $\left(\mathrm{R}^{2}>0.89\right.$; Fig. 1$)$ and within each oak species $\left(\mathrm{R}^{2}>0.87\right)$. The absence of scattered points in the plots outside the regression line indicated that the mean of the leaf image was always strictly associated to spectrometer point-measurements covering about $0.1 \mathrm{~cm}^{2}$. In all species, $\mathrm{R}^{2}$ values were higher in NIRv ( $>0.98$ ), followed by NDVI (from 0.95) and GNDVI (from 0.83). At T1, $\mathrm{R}^{2}$ values above 0.98 were observed for NDVI and NIRv in all oak species, while they ranged from 0.90 (QI) to 0.95 (QR) for GNDVI (graphs not shown).

\section{NIR-camera VIs and morpho-physiological stress indices}

At T0, all VIs did not differ among treatments within species (Figs. 2, 3, 4), while at T1, control and medium stress generally differed from high water stress (Table 2), and seedlings under MS never showed lower values than $\mathrm{C}$ in any stocktype (Fig. 2).

At T1, NDVI in HS was lower than in C and MS in QR and QI stocktypes (except for Co-K in QI). In QP, within stocktype, generally, no significant difference was observed between HS and C or MS (Fig. 2). For GNDVI, in all stocktypes, the same general picture was found only in QR (HS $<$ MS and C). In the other two species, HS differed from $\mathrm{C}$ or MS only in a few cases (Fig. 3). NIRv results were similar to NDVI, apart more clear discrimination in QR (Fig. 4). Consistency of post-hoc (Tukey HSD or Dunn) tests among VIs and morphological and physiological traits at T1 are reported in Table 2, with QR that showed the highest consistency among results of different parameters. In this species, VIs were consistent with predawn leaf water potential (in all stocktypes) and height increment (in 5 out of 6 stocktypes), while in QP and QI this occurred only for some stocktypes. In QP, VIs provided the same results in three stocktypes, and in two of them such results were in accordance with $\mathrm{H}$ increment results. In QI, accordance among VIs did not occur: NDVI 


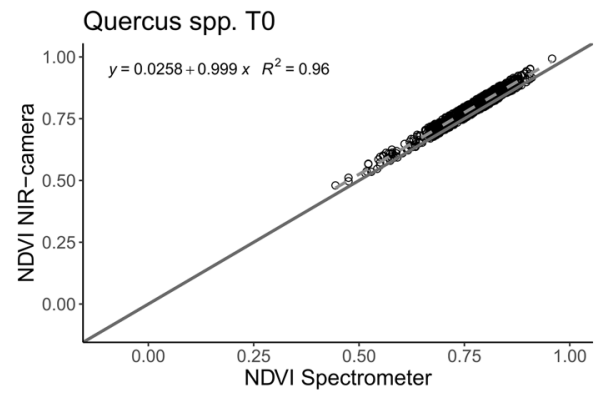

Quercus spp. T0

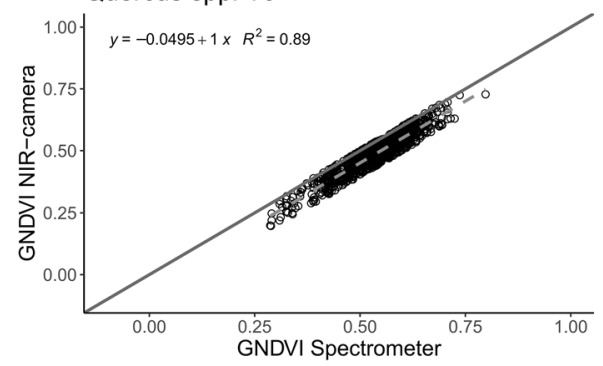

Quercus spp. T0

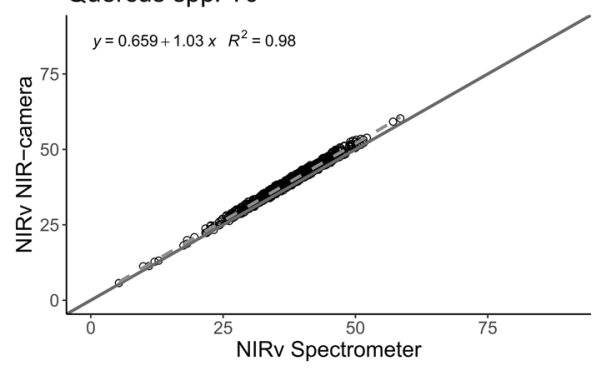

Quercus spp. T1

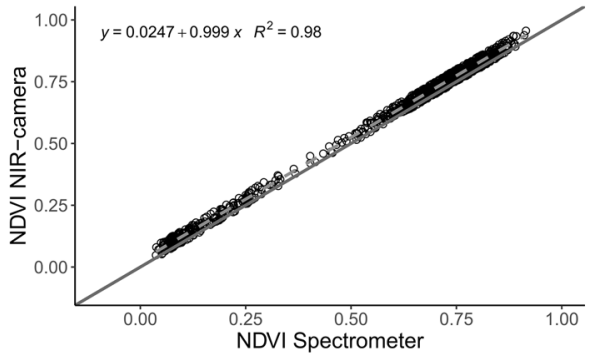

Quercus spp. T1

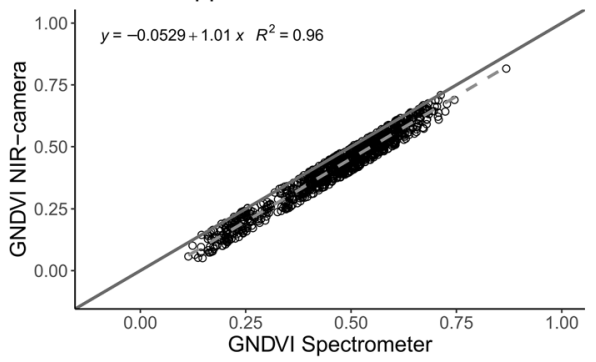

Quercus spp. T1

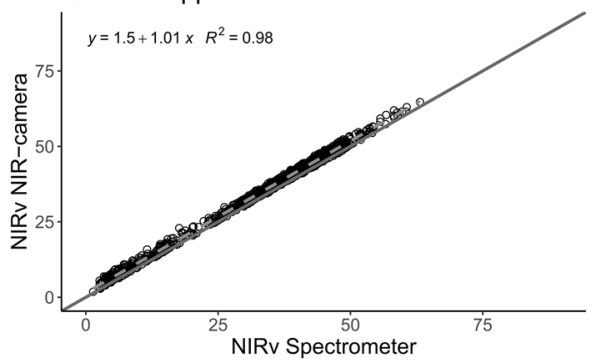

Fig. 1 NIR-camera versus spectrometer comparison for VIs among species (Quercus spp.) at T0 (water stress onset; left) and T1 (maximum water stress; right). Regression line (dashed, in all cases: $P \leq 0.001$ and non-significant intercept) and 1:1 line (solid) are reported

matched GNDVI in two cases, while NIRv never matched GNDVI but only NDVI in four out of six cases. Excluding QI, correlations between the three VIs, on one hand, and height increment, on the other, were significant despite low $r$ values (Table 3).

\section{Chlorophyll content retrieved by spectrometer}

Chlorophyll content $\left(\mathrm{C}_{\mathrm{ab}}\right)$ was not normally distributed (except for MS at T1) and it showed higher values $(P \leq 0.001)$ at $\mathrm{T} 0$ than $\mathrm{T} 1$ (Fig. 5$). \mathrm{C}_{\mathrm{ab}}$ reduction at $\mathrm{T} 1$ was significant for all treatments and not only, as expected, for HS (HS: $-90 \%$; MS: $-20 \%$; C: $-17 \%$ than T1). Discolored spectra (i.e., $\mathrm{C}_{\mathrm{ab}}<5 \mu \mathrm{g} \mathrm{cm}^{-2}$ ) were observed only in leaves under high stress (52\% in total); if discarded, $\mathrm{HS} \mathrm{C}_{\mathrm{ab}}$ values did not significantly deviate from MS $(P>0.15)$ nor $\mathrm{C}(P>0.09)$. The fraction of discolored leaves differed among species; it was highest in QR (78\%) followed by QI (48\%) and QP (30\%). 


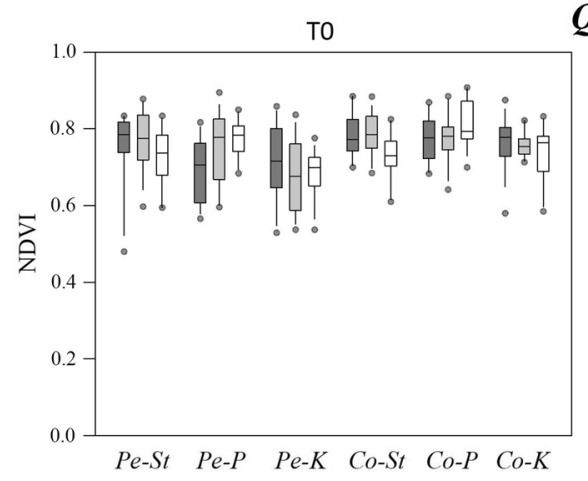

Q. robur

T1
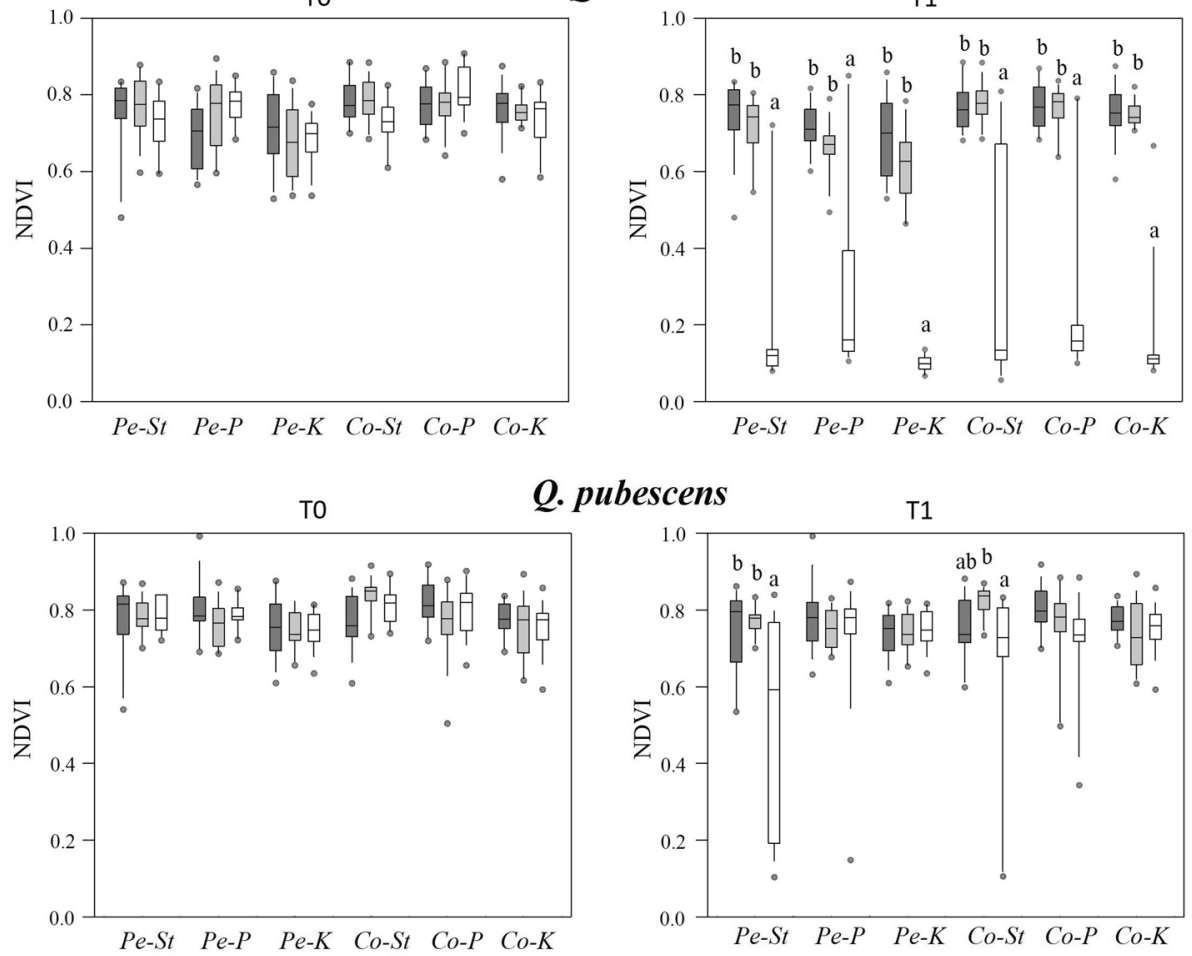

Q. pubescens

T1

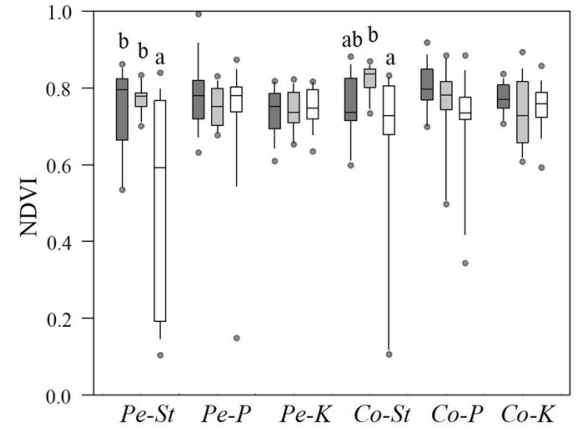

TO

Q. ilex

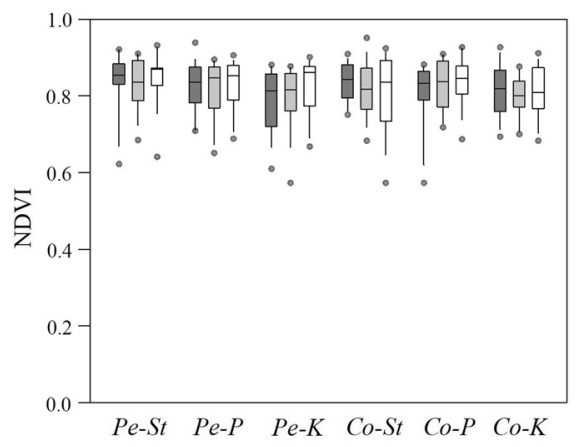

T1

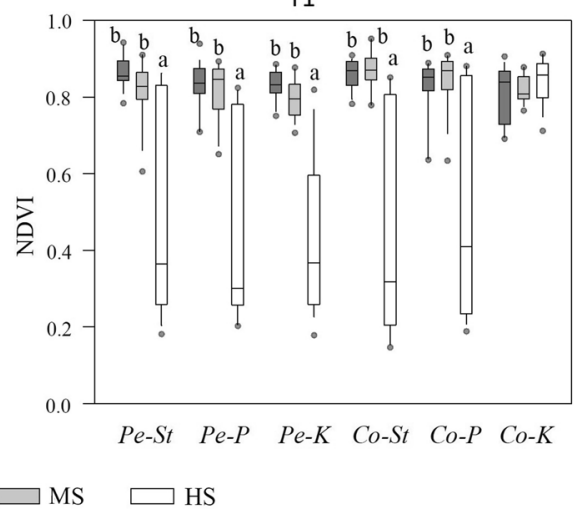

Fig. 2 NDVI boxplots for water stress treatment and stocktypes for Quercus species at T0 (left) and T1 (right). Water-stress levels: black, C; grey, MS; white, HS. Substrate: Pe = peat, Co=coir. Fertilization: $\mathrm{St}=$ standard, $\mathrm{P}=\mathrm{P}$ enriched, $\mathrm{K}=\mathrm{K}$ enriched. Different letters indicate $P \leq 0.05$ for Tukey HSD (or Dunn) test within stocktype

The most sensitive spectral ranges to chlorophyll content apart from red-edge were of particular interest, since the high $\mathrm{R}^{2}$ values observed in the red-edge range (around 700 $\mathrm{nm}$ ) suffered from the circularity inherent in our $\mathrm{C}_{\mathrm{ab}}$ estimation method due to $\mathrm{R}_{705}$ used in $\mathrm{ND}_{705}$. These were assessed by changes in reflectance (Fig. 6) and by $\mathrm{R}^{2}$ changes with 


\section{Q. robur}
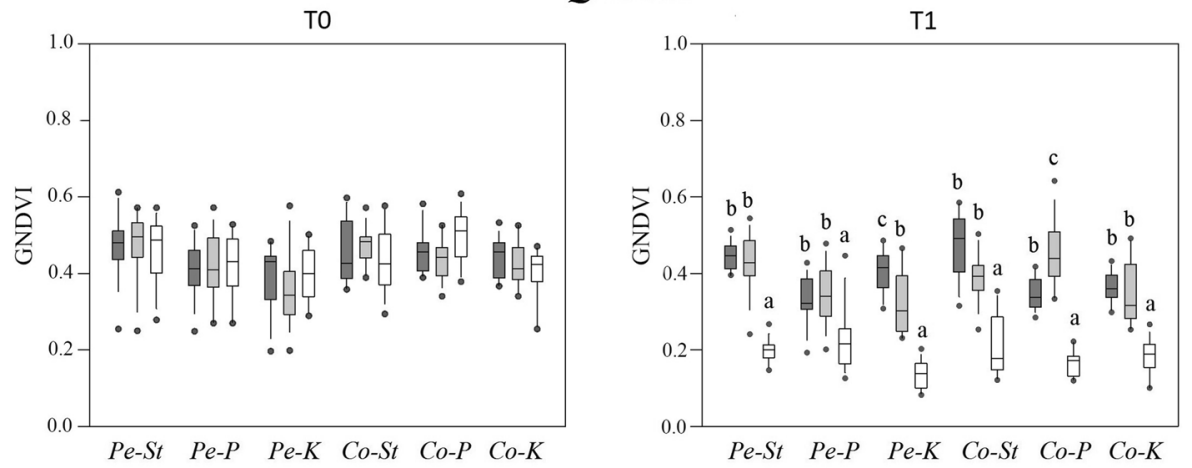

\section{Q. pubescens}
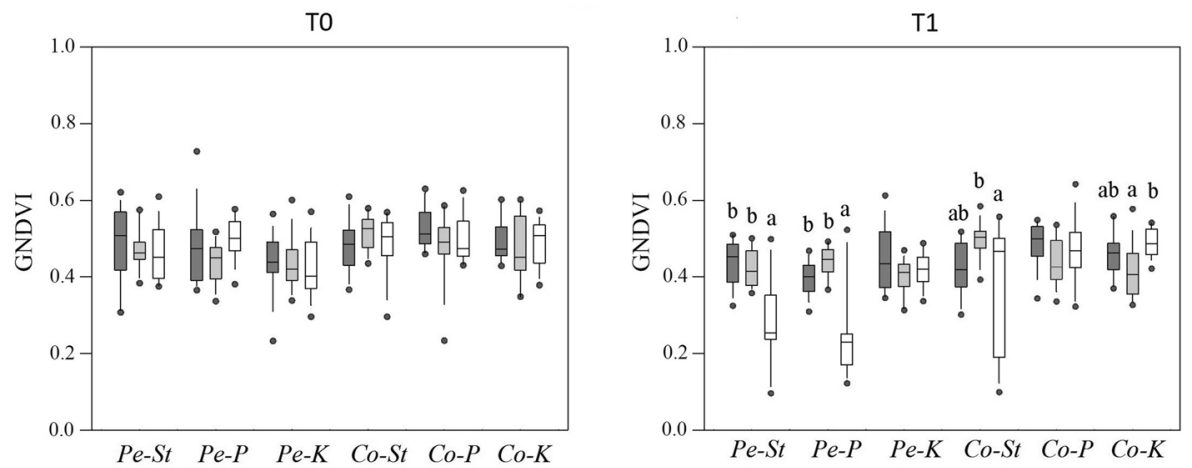

\section{Q. ilex}
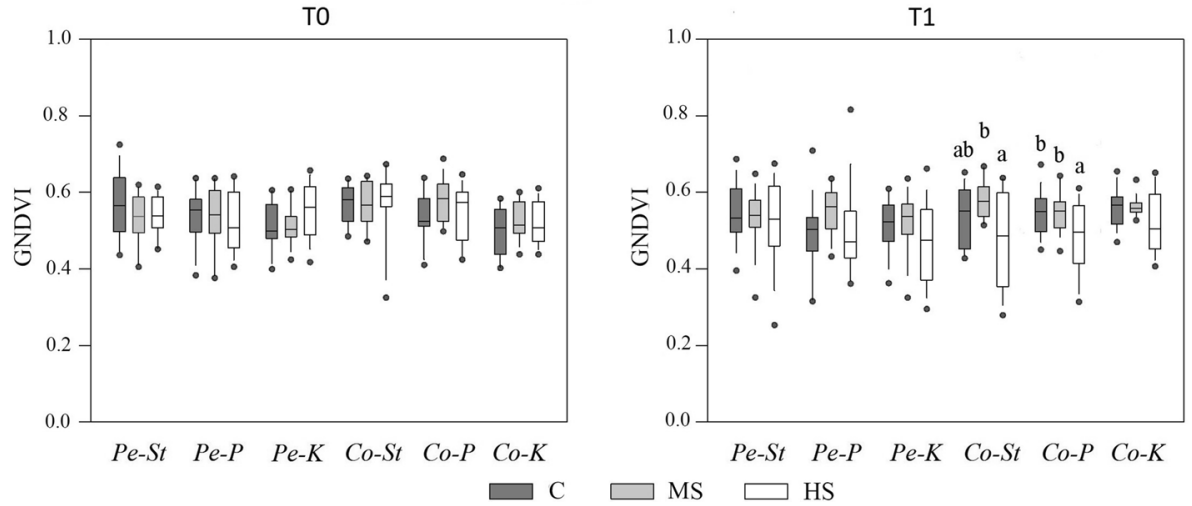

Fig. 3 GNDVI boxplots for water stress treatment and stocktype for Quercus species at T0 (left) and T1 $($ right). Same abbreviations and symbols as Fig. 2

wavelengths between $\mathrm{C}_{\mathrm{ab}}$ and reflectances or vegetation indices (Fig. 7). Overall, chlorophyll reduction was mainly associated with a progressive reflectance increase in the visible range, in accordance with foliar pigment absorption spectra and PROSPECT radiative transfer model (Jacquemoud and Baret 1990; Ustin and Jacquemoud 2020). In green 


\section{Q. robur}
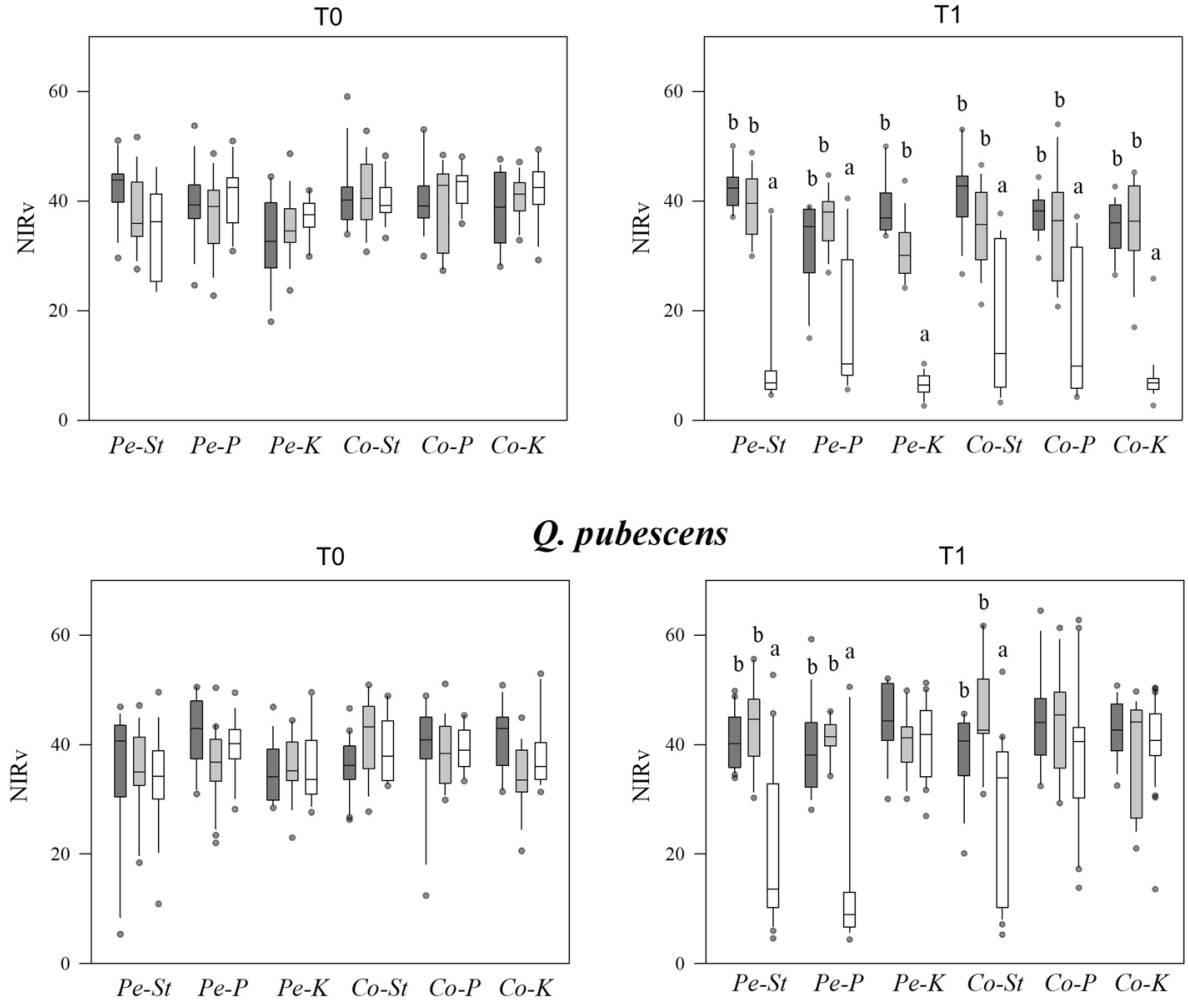

\section{Q. pubescens}
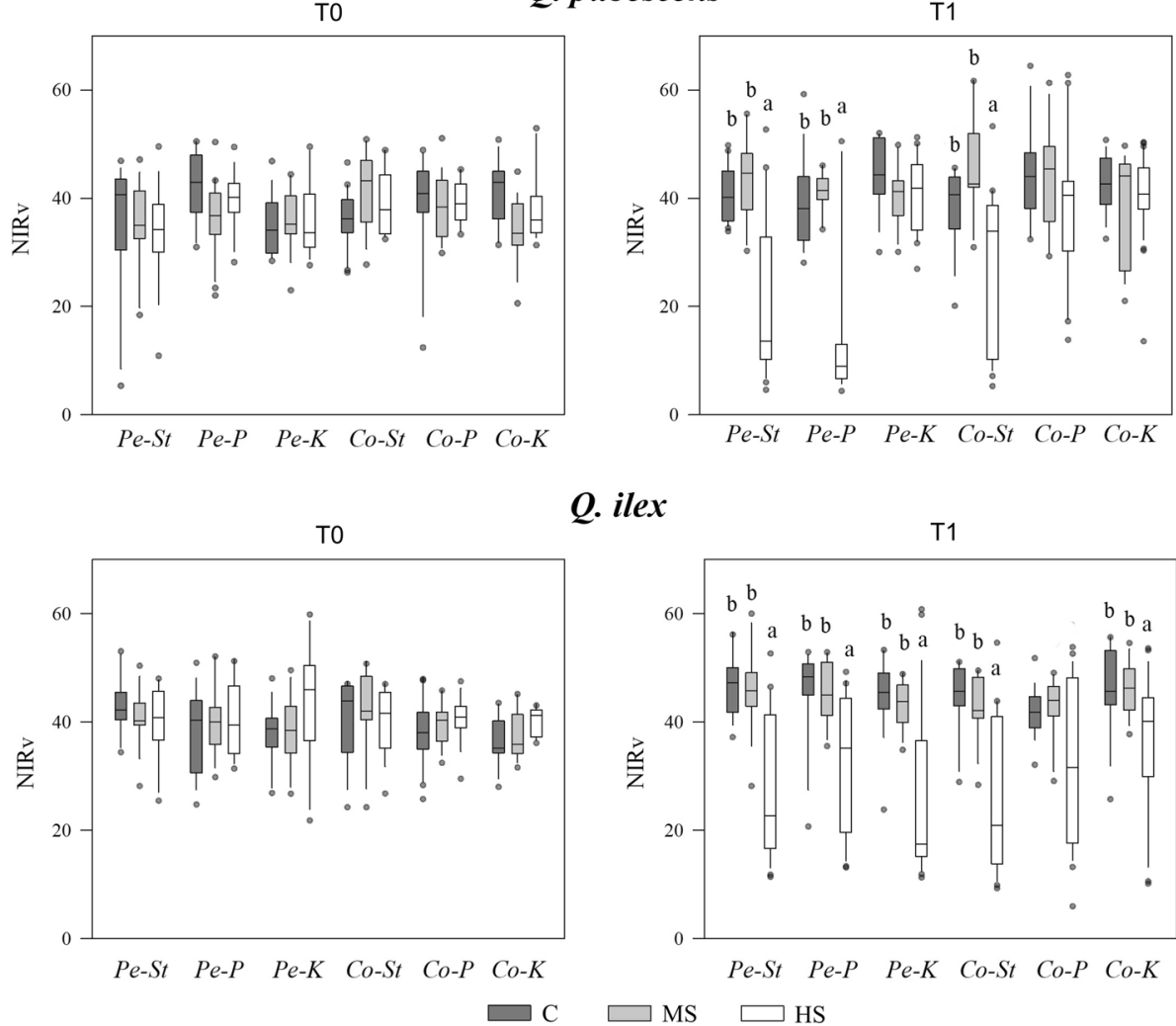

Q. ilex

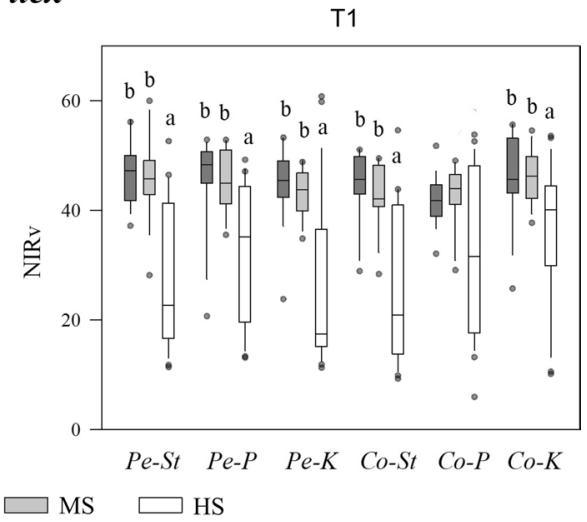

Fig. 4 NIRv boxplots for water stress treatment and stocktype for Quercus species at T0 (left) and T1 (right). Same abbreviations and symbols as Fig. 2

leaves, minimum reflectance variation was observed at $680 \mathrm{~nm}$, where reflectance markedly increased only in strongly damaged leaves, that is when $\mathrm{C}_{\mathrm{ab}}$ dropped below $20 \mu \mathrm{g}$ $\mathrm{cm}^{-2}$ (in QI) or even lower contents for QP and QR, Fig. 6). High responsive regions to $\mathrm{C}_{\mathrm{ab}}$ reduction covered a wide range from blue-green to red $(510-650 \mathrm{~nm} ; P \leq 0.05$ 
Table 2 Consistency among VIs, morphological, and physiological traits in response to water stress levels (Tukey HSD or Dunn test)

\begin{tabular}{|c|c|c|c|c|c|c|c|}
\hline & $\mathrm{Pe}-\mathrm{St}$ & Pe-P & Pe-K & Co-St & Co-P & Co-K & All stocktypes \\
\hline \multicolumn{8}{|l|}{ Q. robur } \\
\hline NDVI & $<0.001^{\mathrm{a}}$ & $<0.001^{\mathrm{a}}$ & $<0.001^{\mathrm{a}}$ & $<0.001^{\mathrm{a}}$ & $<0.001^{\mathrm{a}}$ & $<0.001^{\mathrm{a}}$ & $<0.001^{\mathrm{a}}$ \\
\hline GNDVI & $<0.001^{\mathrm{a}}$ & $<0.001^{\mathrm{a}}$ & $<0.001^{\mathrm{a}}$ & $<0.001^{\mathrm{a}}$ & $<0.001^{\mathrm{a}}$ & $<0.001^{\mathrm{a}}$ & $<0.001^{\mathrm{a}}$ \\
\hline NIRv & $<0.001^{\mathrm{a}}$ & $<0.001^{\mathrm{a}}$ & $<0.001^{\mathrm{a}}$ & $<0.001^{\mathrm{a}}$ & $<0.001^{\mathrm{a}}$ & $<0.001^{\mathrm{a}}$ & $<0.001^{\mathrm{a}}$ \\
\hline Height incr & $0.011^{\mathrm{a}}$ & $0.013^{\mathrm{a}}$ & $<0.001^{\mathrm{a}}$ & $0.011^{\mathrm{a}}$ & $0.100 \mathrm{~ns}$ & $0.002^{\mathrm{a}}$ & $<0.001^{\mathrm{a}}$ \\
\hline $\mathrm{Fv} / \mathrm{Fm}$ & $0.613 \mathrm{~ns}$ & $0.214 \mathrm{~ns}$ & $0.202 \mathrm{~ns}$ & $0.006^{\mathrm{a}}$ & $0.067 \mathrm{~ns}$ & $<0.001^{\mathrm{a}}$ & $<0.001^{\mathrm{a}}$ \\
\hline$\Psi_{\mathrm{PDL}}$ & $<0.001^{\mathrm{a}}$ & $<0.001^{\mathrm{a}}$ & $<0.001^{\mathrm{a}}$ & $<0.001^{\mathrm{a}}$ & $0.004^{\mathrm{a}}$ & $<0.001^{\mathrm{a}}$ & $<0.001^{\mathrm{a}}$ \\
\hline \multicolumn{8}{|c|}{ Q. pubescens } \\
\hline NDVI & $<0.001^{\mathrm{a}}$ & $0.545 \mathrm{~ns}$ & $0.792 \mathrm{~ns}$ & $0.008^{\mathrm{b}}$ & $0.076 \mathrm{~ns}$ & $0.305 \mathrm{~ns}$ & $<0.001^{\mathrm{a}}$ \\
\hline GNDVI & $<0.001^{\mathrm{a}}$ & $<0.001^{\mathrm{a}}$ & $0.129 \mathrm{~ns}$ & $0.016^{\mathrm{b}}$ & $0.184 \mathrm{~ns}$ & $0.002^{\mathrm{c}}$ & $<0.001^{\mathrm{a}}$ \\
\hline NIRv & $<0.001^{\mathrm{a}}$ & $<0.001^{\mathrm{a}}$ & $0.150 \mathrm{~ns}$ & $<0.001^{\mathrm{a}}$ & $0.154 \mathrm{~ns}$ & $0.636 \mathrm{~ns}$ & $<0.001^{\mathrm{a}}$ \\
\hline Height incr & $0.011^{\mathrm{a}}$ & $0.004^{\mathrm{a}}$ & $0.471 \mathrm{~ns}$ & $0.032^{\mathrm{a}}$ & $0.003^{\mathrm{a}}$ & $0.376 \mathrm{~ns}$ & $<0.001^{\mathrm{d}}$ \\
\hline $\mathrm{Fv} / \mathrm{Fm}$ & $0.393 \mathrm{~ns}$ & $0.116 \mathrm{~ns}$ & $0.030^{\mathrm{d}}$ & $0.861 \mathrm{~ns}$ & $0.888 \mathrm{~ns}$ & $0.562 \mathrm{~ns}$ & $0.069 \mathrm{~ns}$ \\
\hline$\Psi_{\mathrm{PDL}}$ & $0.101 \mathrm{~ns}$ & $<0.001^{\mathrm{a}}$ & $<0.001^{\mathrm{a}}$ & $0.473 \mathrm{~ns}$ & $0.003^{\mathrm{a}}$ & $0.022^{\mathrm{a}}$ & $<0.001^{\mathrm{a}}$ \\
\hline \multicolumn{8}{|l|}{ Q. ilex } \\
\hline NDVI & $<0.001^{\mathrm{a}}$ & $<0.001^{\mathrm{a}}$ & $<0.001^{\mathrm{a}}$ & $<0.001^{\mathrm{a}}$ & $<0.001^{\mathrm{a}}$ & $0.192 \mathrm{~ns}$ & $<0.001^{\mathrm{a}}$ \\
\hline GNDVI & $0.675 \mathrm{~ns}$ & $0.106 \mathrm{~ns}$ & $0.088 \mathrm{~ns}$ & $0.007^{\mathrm{b}}$ & $0.018^{\mathrm{a}}$ & $0.074 \mathrm{~ns}$ & $<0.001^{\mathrm{a}}$ \\
\hline NIRV & $<0.001^{\mathrm{a}}$ & $<0.001^{\mathrm{a}}$ & $<0.001^{\mathrm{a}}$ & $<0.001^{\mathrm{a}}$ & $0.172 \mathrm{~ns}$ & $<0.006^{\mathrm{a}}$ & $<0.001^{\mathrm{a}}$ \\
\hline Height incr & $0.118 \mathrm{~ns}$ & $0.027^{\mathrm{a}}$ & $0.004^{\mathrm{a}}$ & $0.006^{\mathrm{a}}$ & $0.607 \mathrm{~ns}$ & $0.359 \mathrm{~ns}$ & $<0.001^{\mathrm{d}}$ \\
\hline $\mathrm{Fv} / \mathrm{Fm}$ & $0.002^{\mathrm{a}}$ & $0.002^{\mathrm{a}}$ & $0.053 \mathrm{~ns}$ & $0.013^{\mathrm{b}}$ & $<0.001^{\mathrm{a}}$ & $0.004^{\mathrm{a}}$ & $<0.001^{\mathrm{a}}$ \\
\hline$\Psi_{\mathrm{PDL}}$ & $0.028^{\mathrm{e}}$ & $0.028^{\mathrm{a}}$ & $0.028^{\mathrm{a}}$ & $0.117 \mathrm{~ns}$ & $0.025^{\mathrm{a}}$ & $0.001^{\mathrm{a}}$ & $<0.001^{\mathrm{a}}$ \\
\hline
\end{tabular}

VIs: NDVI, GNDVI and NIRv by NIR-camera; Height incr (height increment), Fv/Fm (ratio of variable, $\mathrm{Fv}$, to maximum, Fm, fluorescence); $\Psi_{\mathrm{PDL}}$ (predawn leaf water potential). ANOVA (or Kruskal-Wallis) $P$ values were reported

ns $=$ not significant for $\alpha=0.05$

${ }^{\mathrm{a}} \mathrm{HS}<\mathrm{C}$

${ }^{\mathrm{b}} \mathrm{MS}>\mathrm{HS}$

${ }^{\mathrm{c}} \mathrm{HS}>\mathrm{MS}$

${ }^{\mathrm{d}} \mathrm{C}>\mathrm{MS}$

${ }^{\mathrm{e}} \mathrm{MS}>\mathrm{C}$

Table 3 Correlation analysis between height increment and VIs at T1 including discolored leaves

\begin{tabular}{lllll}
\hline & Quercus spp. & Q. robur & Q. ilex & Q. pubescens \\
\hline NDVI versus Height incr & $0.31 * * *$ & $0.43^{* * *}$ & 0.20 & $0.27 * * *$ \\
GNDVI versus Height incr & $0.24 * * *$ & $0.35^{* * *}$ & 0.03 & $0.25^{*}$ \\
NIRv versus Height incr & $0.27 * * *$ & $0.37 * * *$ & 0.18 & $0.26 * * *$ \\
\hline
\end{tabular}

Pearson correlation coefficient $(r)$ and its significance level $(* P \leq 0.05 ; * * * P \leq 0.001)$

for all wavelengths) with the maximum sensitivity at about $550 \mathrm{~nm}$ (Fig. 7); the range included both $\mathrm{R}_{550}$ and $\mathrm{R}_{625}$ NIR-camera nominal bands. High $\mathrm{R}^{2}$ values were observed 

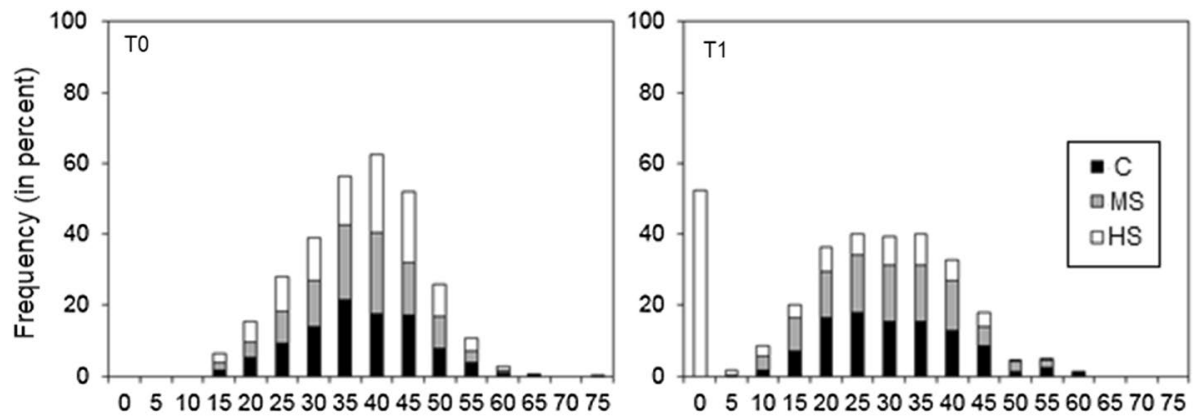

Chlorophyll content $\left(\mu \mathrm{cm}^{-2}\right)$

Fig. 5 Frequency histogram for chlorophyll content at T0 and T1 ( $n_{\text {obs. }}=810$ and 984 leaves). Discolored leaves $\left(\mathrm{C}_{\mathrm{ab}}\right.$ class $\left.0-5 \mu \mathrm{g} \mathrm{cm}^{-2}\right)$ were observed only at $\mathrm{T} 1$

in a narrower spectral range, i.e., in the green-yellow at $\mathrm{T} 0$ and the yellow-orange region at $\mathrm{T} 1$ or $\mathrm{T} 0+\mathrm{T} 1$ (Fig. 7). Among fitting methods, the exponential function returned the best results for $C_{a b}$ estimation $\left(\mathrm{R}^{2}>0.9\right.$ over a $100-120 \mathrm{~nm}$-wide shoulder at T1). This range stretched from $700 \mathrm{~nm}$ to about $600 \mathrm{~nm}$ (orange) for reflectance, and further to 583 $\mathrm{nm}$ for VIs (i.e., till yellow with $\max \mathrm{R}^{2}$ at $635 \mathrm{~nm}$ in both cases). Quadratic interpolation showed $R^{2}>0.9$ over a more restricted range outside the red-edge, covering about 70 $\mathrm{nm}$ for VIs (range: $573-638 \mathrm{~nm}$; $\max \mathrm{R}^{2}=0.94$ at $603 \mathrm{~nm}$ ), where reflectance bands also showed good $\mathrm{R}^{2}$ values, with a maximum at $592 \mathrm{~nm}$. Correlograms at $\mathrm{T0}$ (well-watered plants) strongly differed in pattern from $\mathrm{T} 1$ and $\mathrm{T} 0+\mathrm{T} 1$ datasets (which included green and discolored leaves) under several relevant aspects (Fig. 7). Firstly, at T0, linear interpolation fitted the data equally as well as non-linear functions, thus the former should be used in absence of discolored leaves. Secondly, VIs showed a marked fall of $R^{2}(<0.5)$ in the red range $(650-690 \mathrm{~nm})$ with a minimum $\mathrm{R}^{2}$ at $678 \mathrm{~nm}$, which was also confirmed for reflectance-band correlograms. Then, at T0, high $\mathrm{R}^{2}$ values $(>0.9)$ were found (both for VIs and reflectance bands and besides red-edge) in a narrow $14 \mathrm{~nm}$-wide range (558-572 $\mathrm{nm}$, green-yellow) with the maximum value $\left(\mathrm{R}^{2}=0.91\right)$ at $565 \mathrm{~nm}$, blue-shifted by about $70 \mathrm{~nm}$ in respect to the whole dataset. Moreover, the increase in $\mathrm{R}^{2}$ values due to VI normalization on $850 \mathrm{~nm}$ was particularly relevant at $\mathrm{T} 1$, when a high variability in $\mathrm{C}_{\mathrm{ab}}$ was observed. Given the different results between datasets, we further tested the role of HS treatment and discolored leaves: removing HS leaves or even only discolored leaves gave similar correlograms to T0 without relevant differences between linear and non-linear fitting results (Appendix 1 and 2).

\section{Chlorophyll content retrieved by NIR-camera}

At leaf level, the NIR-camera showed very high $\mathrm{R}^{2}$ values for $\mathrm{C}_{\mathrm{ab}}$ estimation by VIs, confirming spectrometer results. The main difference between NDVI and the other two indices (GNDVI and NIRv) or between $\mathrm{R}_{625}$ and $\mathrm{R}_{550}$ was that a single equation was sufficient to estimate $\mathrm{C}_{\mathrm{ab}}$ in the whole dataset for NDVI only (or $\mathrm{R}_{625}$ ). For NIRv, GNDVI or $\mathrm{R}_{550}$, it is necessary to discriminate between discolored and non-discolored leaves to reliably estimate chlorophyll content. The exponential fitting function for NDVI for the entire $C_{a b}$ variability observed in the whole dataset $\left(R^{2}>0.97\right.$, both devices) was reported in Fig. 8. Similarly to NDVI, reflectance at $625 \mathrm{~nm}\left(\mathrm{R}_{625}\right)$ was able to estimate 

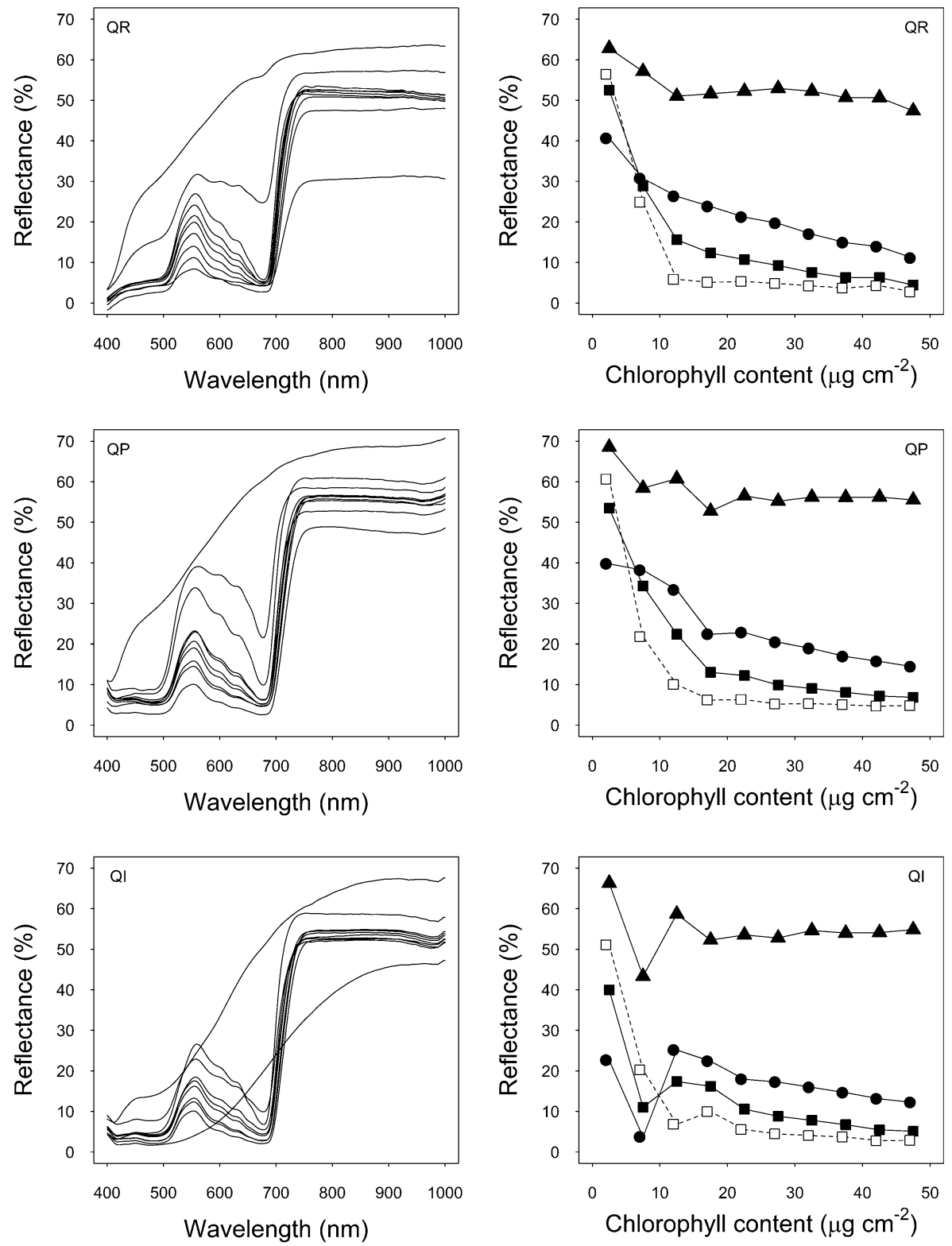

Fig. 6 Right. Spectrometer reflectance for selected wavelengths (filled circle: $550 \mathrm{~nm}$; filled square: 625 $\mathrm{nm}$; open square: $680 \mathrm{~nm}$; filled triangle: $850 \mathrm{~nm}$ ). Species: $\mathrm{QR}=$ Quercus robur; $\mathrm{QP}=Q$. pubescens; $\mathrm{QI}=Q$. ilex. $\mathrm{T} 1$ dataset. Left. Average spectrometer reflectance spectra per chlorophyll content class; to derive $\mathrm{C}_{\mathrm{ab}}$ class see $\mathrm{R}_{550}$ or $\mathrm{R}_{680}$ symbols on the correspondent figure on the right; $\mathrm{C}_{\mathrm{ab}}$ classes $\geq 45 \mu \mathrm{g} \mathrm{cm}{ }^{-2}$ were merged

chlorophyll content with $\mathrm{R}^{2}$ of about 0.9 (overall, camera: $\mathrm{C}_{\mathrm{ab}}=56.431 \cdot \operatorname{EXP}\left(-0.06 \cdot \mathrm{R}_{625}\right)$, $\mathrm{R}^{2}=0.89$; spectrometer: $\left.\mathrm{C}_{\mathrm{ab}}=57.355 \cdot \mathrm{EXP}\left(-0.07 \cdot \mathrm{R}_{625}\right), \mathrm{R}^{2}=0.92\right)$. NIR band $\left(\mathrm{R}_{850}\right)$ was linearly better related to NIRv in green leaves $\left(R^{2}=0.567, n=1572\right.$, intercept $=3.187$ 

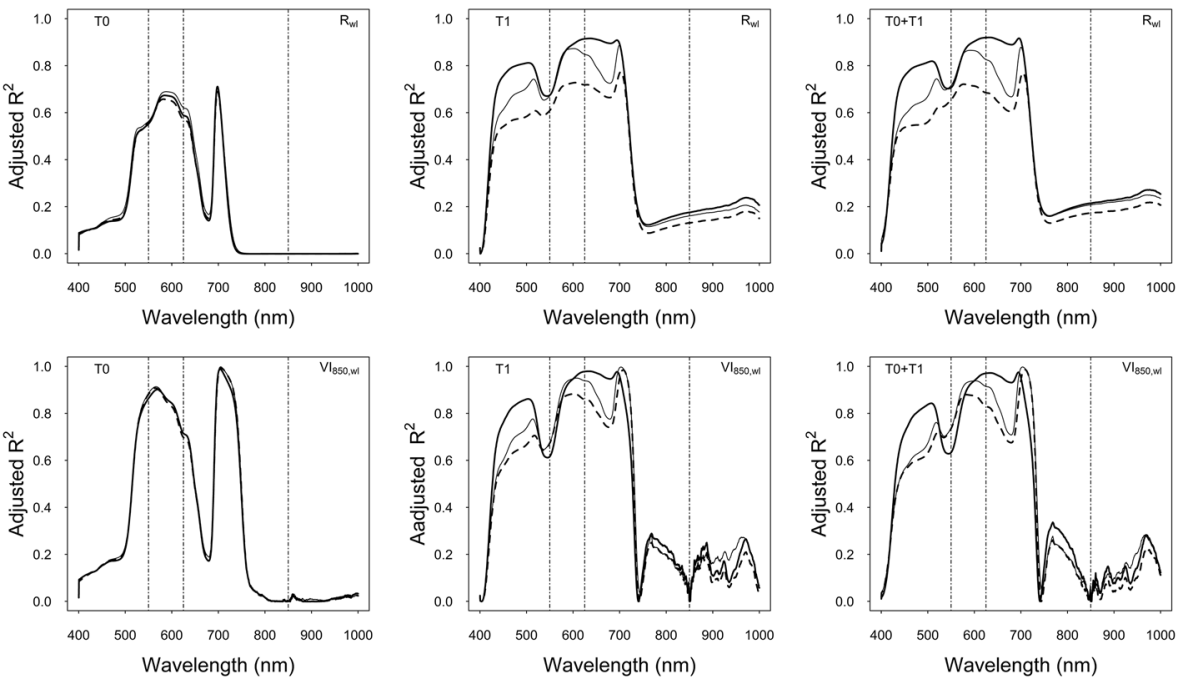

Fig. 7 Correlograms for estimating chlorophyll content $\left(\mathrm{C}_{\mathrm{ab}} \geq 0\right)$ by single reflectance bands, $\mathrm{R}_{\mathrm{wl}}$ (above), or normalized vegetation indices on $850 \mathrm{~nm}, \mathrm{VI}_{850, \mathrm{wl}}=\left(\mathrm{R}_{850}-\mathrm{R}_{\mathrm{wl}}\right) /\left(\mathrm{R}_{850}+\mathrm{R}_{\mathrm{wl}}\right)$ (below). Datasets: before water stress: T0; maximum water stress: T1; overall: T0+T1. Fitting equation: exponential (bold line); quadratic (solid line); linear (dashed line). Vertical dashed lines at nominal NIR-camera bands $\left(\mathrm{R}_{550}, \mathrm{R}_{625}\right.$ and $\left.\mathrm{R}_{850}\right) ; n_{\text {obs. }}=810(\mathrm{~T} 0)$ and 984 (T1) leaves

and slope $=0.702$, both $P<0.001)$ than in discolored leaves $\left(\mathrm{R}^{2}=0.188, \mathrm{n}=222\right.$, intercept $=-3.69, P=0.073$; slope $=0.228, P<0.001$ ). For the other two VIS (NDVI and GNDVI) these relations were nil $\left(\mathrm{R}^{2}\right.$ values below 0.003$)$. NIR band was poorly related to $\mathrm{C}_{\mathrm{ab}}$ (overall, camera: $\mathrm{R}^{2}<0.32$; spectrometer: $\mathrm{R}^{2}<0.20$ ); correlation further dropped $\left(\mathrm{R}^{2}<0.001\right)$ within leaf-type group (i.e., discolored and non-discolored). NIR reflectance was higher in discolored (median, $\mathrm{IQR}=69,57-73$ ) than in green (median, IQR $=51$, 43-54) leaves. $R_{550}$ (Green band) estimated worse than GNDVI (Fig. 8) chlorophyll content both in green leaves $\left(\mathrm{C}_{\mathrm{ab}}=-1.6234 \cdot \mathrm{R}_{550}+62.954, \mathrm{R}^{2}=0.64\right)$ and discolored leaves $\left(\mathrm{C}_{\mathrm{ab}}=-0.0493 \cdot \mathrm{R}_{550}+3.8213, \mathrm{R}^{2}=0.46\right)$. Both GNDVI and $\mathrm{R}_{550}$ showed different equations between discolored and green leaves; the two leaf-types had markedly different slopes $(P \leq 0.05)$, resulting in a large overlap that limited their general use.

\section{Discussion}

\section{VIs comparison between NIR-camera and spectrometer}

The simplicity in the use of a NIR camera-being identical to a common RGB camera from the operative point of view-might offer several applications in the field of plant monitoring and forest restoration. The highly comparable results between the NIR-camera and spectrometer VIs were mainly due to a correct determination of leaf reflectance by tracking the subtle differences in illumination using a white reference. In fact, Nebiker et al. (2016) found with the same NIR-camera a low agreement between spectrometer and image NDVIs without calibration, while high correlations in comparing similar devices 

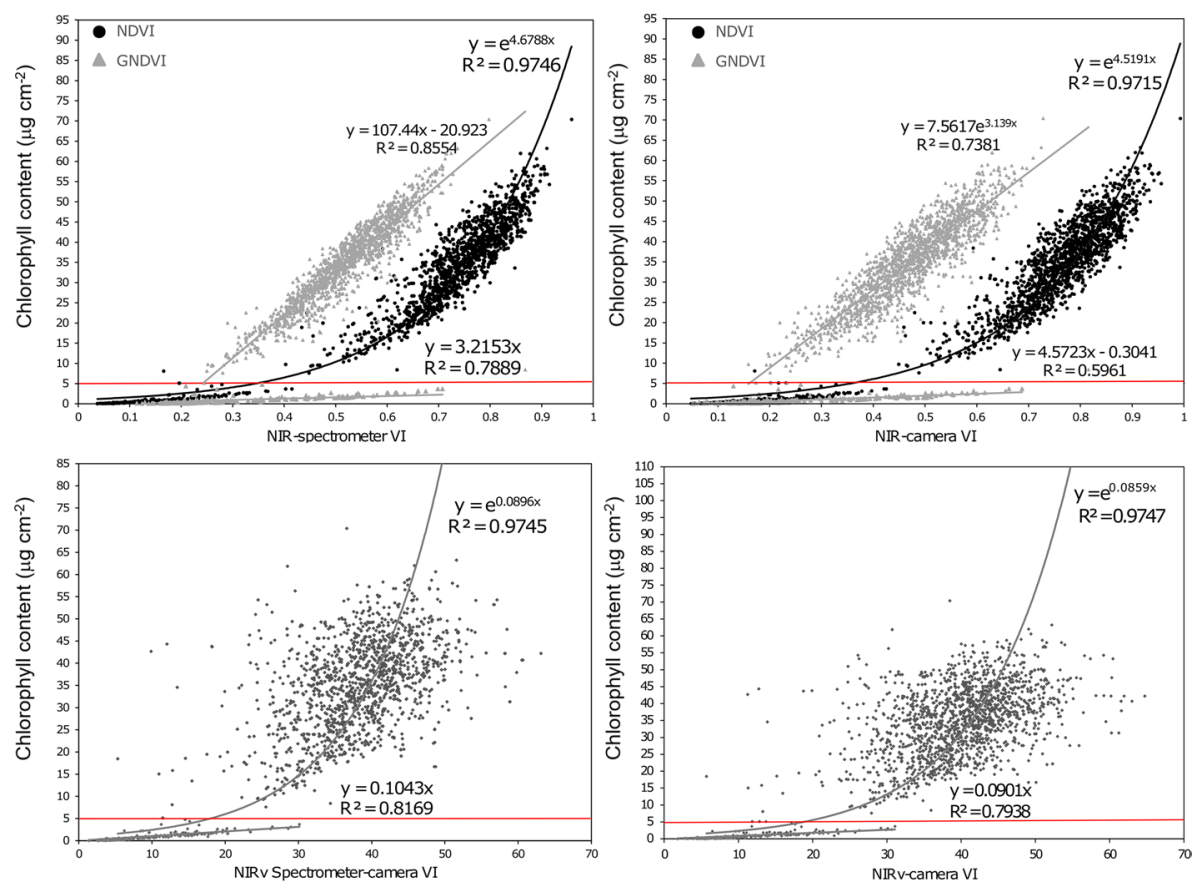

Fig. 8 Whole dataset; chlorophyll content $\left(\mathrm{C}_{\mathrm{ab}}\right)$, and vegetation indices relationships (above: filled black circle, NDVI; filled triangle, GNDVI; below: filled grey circle, NIRv) by VIS/NIR spectrometer (left) and NIR-camera (right); $n_{\mathrm{obs}}=1794$ leaves. Note that GNDVI and NIRv had a different linear equation for discolored leaves $\left(\mathrm{C}_{\mathrm{ab}}<5 \mu \mathrm{g} \mathrm{cm}^{-2}\right)$

were reported only with a proper white reference (Di Gennaro et al. 2018; Chianucci et al. 2019). The high goodness-of-fit also held by UAV at the canopy scale over crops (Di Gennaro et al. 2018), grasslands (Von Bueren et al. 2015) or forests (Weil et al. 2017). Our choice to take measurements at midday under clear-sky and high-sun elevation conditions (early-summer) on leaves acclimated to high irradiance might have strongly contributed to the high correlation found between the two devices, confirming leaf scale results observed by Putra and Soni (2017) for NDVI and the better results obtained at high-irradiance than under diffuse light in four broadleaf tree species (Chianucci et al. 2019). Even though a higher camera signal-to-noise ratio was achieved at high irradiance (Granados et al. 2010), leaf acclimation to the measuring light conditions was also an important aspect. A significant change in reflectance was observed above $300 \mu \mathrm{mol} \mathrm{m} \mathrm{m}^{-2} \mathrm{~s}^{-1}$ photosynthetic active radiation (Wada 2016) and acclimation required more than $30 \mathrm{~min}$ for dark to light transition (or vice versa; Dutta et al. 2017). Thus, it is advisable to take measurements under a similar light environment to that experienced by the leaves (better under saturating light) or to complete acquisitions within a few seconds. Moreover, different view/illumination geometries might result in reflection differences among bands due to leaf anisotropy and bidirectional optical properties (BRDF) (Combes et al. 2007). Nevertheless, within a $45^{\circ}$ incidence angle, similar reflectance values were observed between nadir and backscatter mode, as in NIR-camera and spectrometer setup (Combes et al. 2007; Biliouris et al. 2009). 


\section{Consistency between NIR-camera VIs and morpho-physiological stress indices}

Substrate and fertilization introduced a further source of variability in our sample (Mariotti et al. 2020), which has been useful to test the concordance between NIR-camera VIs and ecophysiological indices, which traced the complex plant responses to drought (e.g., Chaves et al. 2003; Gupta et al. 2020). Among the studied oak species, differences existed in the strategies adopted to face water shortages, balance water uptakes with losses, control growth, and promote survival (Gil-Pelegrín et al. 2017). Q. robur was the most vulnerable to drought, preferring temperate climates without a dry season (Ducousso and Bordacs 2004; Mölder et al. 2019; Bert et al. 2020), while the other two oaks ( $Q$. pubescens and $Q$. ilex) — having both a high tolerance to drought—were mainly found in sub-arid Mediterranean regions (e.g., Gil-Pelegrín et al. 2017).

The morpho-physiological stress indices used in this study were useful to describe both water stress severity and how the plants responded to drought. Height growth rapidly sensed water deficits (Arend et al. 2011), especially in the two deciduous species, $Q$. robur and $Q$. pubescens; the slight positive relationship between VIs and height increment observed in both species could be linked both to the short experimental period (two weeks) compared to vegetative season and to the semi-determinate growth pattern of these oak species with recurrent shoot flushes (Collet and Frochot 1996; Mariotti et al. 2015). Such a pattern alternates single flush elongation periods with growth stasis; thus, during a twoweek timespan, some seedlings might have been in a stage of growth stasis regardless of water regimes, and this might have affected the strength of the correlation response. In $Q$. ilex, this relationship was not significant, suggesting a higher tolerance and different strategy to face drought. Similarly, drought reduced light-saturated rate of photosynthetic carbon uptake and stomatal conductance more in QR and QP than in QI (Cocozza et al. 2020). A significant interaction effect between these oak species and drought, as well with other stressors, such as ozone, was observed by Hoshika et al. (2018) and Cotrozzi et al. (2016), indicating different strategies among the three species.

A reduction of $\Psi_{\mathrm{PDL}}$ under severe stress was found in all species and stocktypes except for standard fertilization for both substrates in $Q$. pubescens and $Q$. ilex, suggesting that only these latter species effectively limited transpiration at the cost of a reduction in leaf VIs (and thus chlorophyll content). In $Q$. pubescens and Q. ilex, Fv/Fm (an absolute measure of PSII photosynthetic efficiency) was found to drop only at a predawn leaf water potential below -4 MPa (Tognetti et al. 1998) showing a marked daily course even at lower $\Psi_{\mathrm{PDL}}$ values (Méthy et al. 1996). Low Fv/Fm values might reflect either the presence of photodamage to the photosynthetic apparatus due to the scavenging of impaired reactive oxygen species (ROS) or the capability of the leaf to adopt a long-lasting photoprotected state, when the level of light and stress exceeded the capacity to utilize photosynthates (DemmigAdams et al. 2012; Noctor et al. 2018). Moreover, in response to drought, both $Q$. ilex and $Q$. pubescens had an additional defense mechanism to high light decreasing NDVI (and thus chlorophyll content) in leaves; a phenomenon we found more marked in $Q$. ilex than $Q$. pubescens. As expected, $Q$. robur was strongly vulnerable to severe drought, showing a larger reduction in growth, $\Psi_{\mathrm{PDL}}$ and $\mathrm{Fv} / \mathrm{Fm}$, together with changes in VIs consistent to paler leaves in functional ('green') leaves. These traits were accompanied by complete leaf desiccation for about two-thirds of the leaves. Leaf mortality, which is commonly observed in this species under drought, has been related to hydraulic failure and its vulnerability to xylem embolism (the highest among the three species; see Lobo et al. 2018). 
The absence of a significant effect on growth, VIs, and ecophysiological indices (in all species and stocktypes) with water availability halved compared to field capacity (i.e., in MS) should pave the way to a more sustainable water-resource use when growing these oak species in nurseries, in line with setting research-based best-management practices to minimize water needs as suggested in Majsztrik et al. (2017) review.

\section{Chlorophyll content and optical devices}

Chlorophyll content might accurately be retrieved in situ by $705 \mathrm{~nm}$ and $750 \mathrm{~nm}$ normalized difference index $\left(\mathrm{ND}_{705}\right)$, where the red-edge band sensed the chlorophyll signal (Sims and Gamon 2002) and the NIR band acts as a reference, since it was not influenced by pigment effects (Féret et al. 2008). The choice of $\mathrm{ND}_{705}$ over other formulations (see Jacquemoud and Ustin 2019 for a detailed list) was driven by the ample Féret et al. (2011) dataset, which allowed to retrieve an empirical, yet robust, equation to estimate chlorophyll content. Recently, a strong and linear relationship between $\mathrm{ND}_{705}$ and chlorophyll concentration (weight/weight) was also reported (Lin et al. 2013).

Our results showed that $\mathrm{C}_{\mathrm{ab}}$ might be estimated by almost every visible wavelength (above $450 \mathrm{~nm}$ ), while near-infrared bands were insensitive to chlorophyll content, as NIR reflectance was mainly related to leaf thickness or structure (Féret et al. 2008). Reflectance at $850 \mathrm{~nm}$ is moderately related to anatomical leaf parameters both within (as in Q.ilex; Ourcival et al. 1999) and among species, driven by the ratio of mesophyll cell surface to intercellular air spaces (Knapp and Carter 1998; Serrano 2008). With season and drought, we observed an increase in reflectance at $850 \mathrm{~nm}$, amounting to $10 \%$ for season in wellwatered conditions $(\mathrm{C}+\mathrm{MS})$ and to $+12 \%$ for severe stress (HS respect to the control) at $\mathrm{T} 1$. The high $\mathrm{R}_{850}$ observed under severe stress was due to the presence of discolored leaves $(+23 \%$ respect to control) indicating a relevant change in leaf structure; when excluded, the difference respect to control was negligible $(0.3 \%)$. Consequently, $\mathrm{R}_{850}$ increase (relative to the control) was consistent in HS with discolored-leaf fraction in crown (and visual perception of plant status) for the three species. Normalization with reflectance at $850 \mathrm{~nm}$ improved chlorophyll estimate not only under well-watered conditions but also under all conditions that did not include discolored leaves, indicating a residual effect of leaf structure in the estimate of $\mathrm{C}_{\mathrm{ab}}$, which is only partly captured by reflectance at $750 \mathrm{~nm}$.

In this study, NDVI (obtained by $850 \mathrm{~nm}$ and $625 \mathrm{~nm}$ reflectances) covered nearly the full range of values from 0.04 to 0.96 - close to its theoretical values of 0 and 1 . Remarkably, the first logarithmic relation between leaf reflectance and total chlorophyll content included reflectance at $625 \mathrm{~nm}$ (Benedict and Swidler 1961; Jacquemoud and Ustin 2019). Spectrometer and NIR-camera NDVI, GNDVI, and NIRv were highly correlated with chlorophyll content (NDVI, $\mathrm{R}^{2}=0.94$; GNDVI, $\mathrm{R}^{2}=0.72$, NIRv, $\mathrm{R}^{2}=0.97$ ), and although few studies compared camera VIs with chlorophyll content, high goodness-of-fit was found for a temperate forest $\left(\mathrm{R}^{2}=0.73\right.$; Yang et al. 2017) or at leaf scale $\left(\mathrm{R}^{2}\right.$ from 0.82 to 0.93 ; Hosoi et al. 2019, $\mathrm{R}^{2}=0.94$; Chung et al. 2018) with NIR smartphone cameras. Between NDVI and GNDVI or NIRv, the former was a better estimator of $\mathrm{C}_{\mathrm{ab}}$, as the latter two were unable to reliably estimate chlorophyll content in the presence of discolored leaves. Nevertheless, when only 'green' (that is, 'not discolored') leaves were taken into account GNDVI and NIRv performed comparably to NDVI, pointing out the importance of discolored leaves and how to treat them statistically. Accounting for their presence and incidence might be useful to classify water stress intensity and species responses. Moreover, discoloredleaf reflectance spectra might be used as end-members for modeling or up-scaling stress 
detection to canopy or broader spatial scales. At satellite scale, reflectance at $625 \mathrm{~nm}$ was included in WorldView-3 (and WorldView-2) yellow band, ranging from 585 (589) nm to 625 (627) nm (spatial resolution below 2 m; Updike and Comp 2010; Kuester 2016) and showing similar results to the red-edge spectral band (Sibanda et al. 2017). We confirmed the strong relationship to chlorophyll content for WorldView yellow-band nominal spectral-interval, placed next to the $583 \mathrm{~nm}$ wavelength, where we found the best $\mathrm{R}^{2}$ between chlorophyll content and VIs normalized with NIR reflectance at $850 \mathrm{~nm}$. Our results were corroborated by several applications of the WorldView yellow band in forestry, from tree species classification (Immitzer et al. 2012; He et al. 2019) to invasive grass detection (Marshall et al. 2012), also by normalized indices (Wolf 2012) and chlorophyll estimation (Lin 2018; Lin and Lin 2019).

\section{Conclusions}

According to our results, the use of an affordable NIR-camera might offer a promising and reliable approach, for the following points:

- to detect vegetation indices (NDVI, GNDVI and NIRv) with results highly comparable to a narrowband VIS/NIR spectrometer (following a simple protocol during image acquisition, i.e., calibration and standard geometry);

- to estimate chlorophyll content with a very high goodness-of-fit by VIs or reflectance bands in the visible range. For general purposes, NDVI performed better than GNDVI and NIRv; vegetation indices performed better than the single reflectance bands. NDVI reliably fitted $\mathrm{C}_{\mathrm{ab}}$ for the full range of variation given by species, stocktypes and drought stresses. Promising results were observed for GNDVI and NIRv, when discolored leaves were excluded from sample.

- to help in drought-stress early-monitoring in oak seedlings, quantifying water stress occurring over a brief period. Even if the physiological responses of three oak species to drought were different, more negative predawn leaf water potential values were related to a reduction of all VIs (and thus chlorophyll content).

In conclusion, NIR-camera imagery might be applied to drought-stress early-monitoring in oak seedlings, saplings, or small trees in the post-planting phase or in nursery conditions. This approach offers a strongly reliable alternative to data collection where costs and ease of use ae crucial, such as in the context of restoration programs where available financing is usually limited. However, it would be advisable to test a larger set of conditions and plant species to draw more general conclusions.

\section{Appendix 1}

See Fig. 9. 

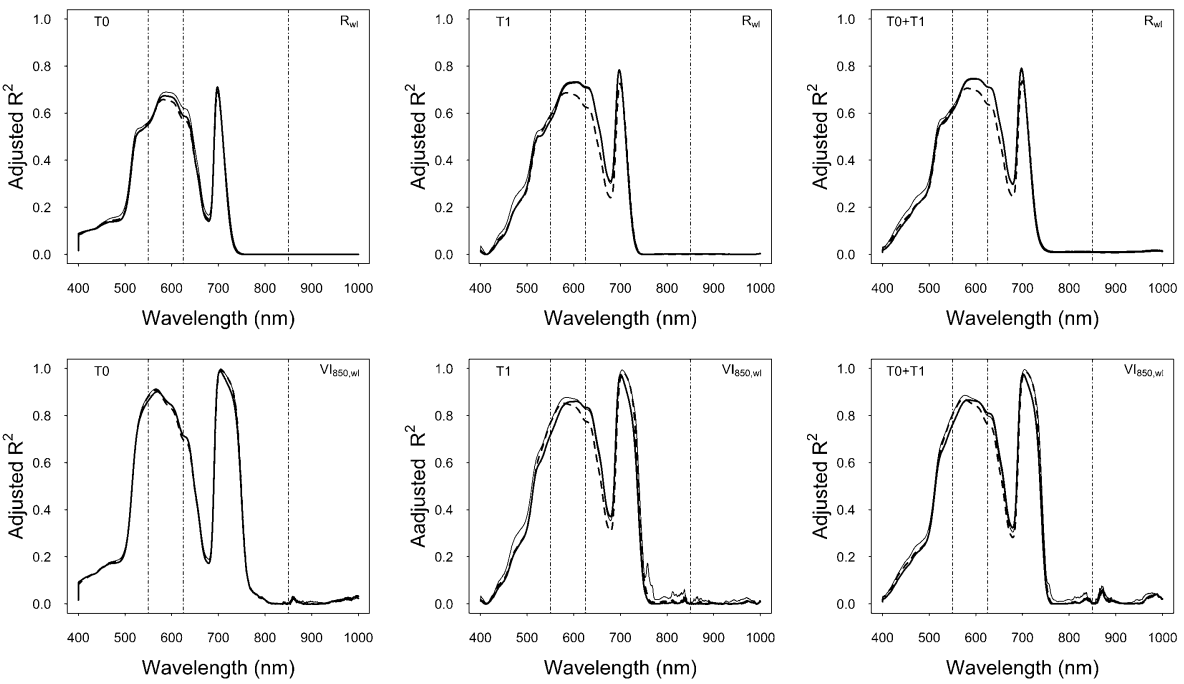

Fig. 9 Correlograms for $\mathrm{C}_{\mathrm{ab}} \geq 5 \mu \mathrm{g} \mathrm{cm} \mathrm{cm}^{-2}$ (i.e., discolored measurements excluded). Single reflectance bands, $\mathrm{R}_{\mathrm{wl}}$ (above), or normalized vegetation indices on $850 \mathrm{~nm}, \mathrm{VI}_{850, \mathrm{wl}}=\left(\mathrm{R}_{850}-\mathrm{R}_{\mathrm{wl}}\right) /\left(\mathrm{R}_{850}+\mathrm{R}_{\mathrm{wl}}\right)$ (below). Datasets: before water stress, T0; maximum water stress, T1; overall, T0 $+\mathrm{T} 1$. Fitting equation: exponential (bold line); quadratic (solid line); linear (dashed line). Vertical dashed lines at nominal NIR-camera bands $\left(\mathrm{R}_{550}, \mathrm{R}_{625}\right.$, and $\left.\mathrm{R}_{850}\right) ; n_{\text {obs. }}=810$ (T0) and 762 (T1) leaves

\section{Appendix 2}

See Fig. 10.
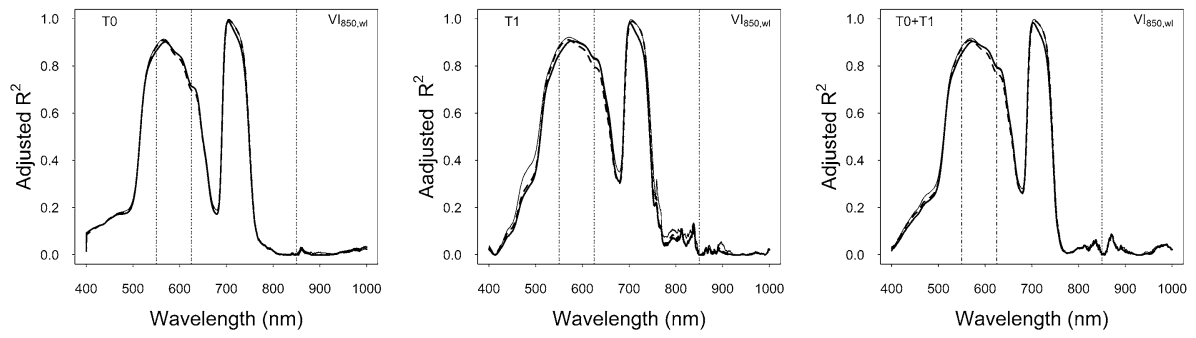

Fig. 10 Correlograms for C+MS treatments (i.e, HS treatment excluded); $n_{\text {obs. }}=552$ (T0) and 550 (T1) leaves. Same symbols and abbreviations from Appendix 1

Acknowledgements We wish to thank Fabio Bandini and Stefano Teri (DAGRI, University of Florence) for technical assistance and experiment maintenance. We acknowledge Andrew Francis Speak (DAGRI, University of Florence) for having improved the language editing. We are particularly indebted to Emilio Resta (Vannucci Piante) for sharing his valuable expertise. We are grateful to Vannucci Piante, project partner, for the high quality of the nursery facilities. This study is dedicated to the dear memory of Ivan Pippi (IFAC-CNR, Italy), who introduced SR to the methods and techniques for optical remote sensing. Project: VIAA Vivaistica Innovativa ad Alta Adattabilità Mis-16.2 in Verdi Connessioni in PSR- FEASR 2014-2020 Regione Toscana 
Funding Open access funding provided by Università degli Studi di Firenze within the CRUI-CARE Agreement.

Open Access This article is licensed under a Creative Commons Attribution 4.0 International License, which permits use, sharing, adaptation, distribution and reproduction in any medium or format, as long as you give appropriate credit to the original author(s) and the source, provide a link to the Creative Commons licence, and indicate if changes were made. The images or other third party material in this article are included in the article's Creative Commons licence, unless indicated otherwise in a credit line to the material. If material is not included in the article's Creative Commons licence and your intended use is not permitted by statutory regulation or exceeds the permitted use, you will need to obtain permission directly from the copyright holder. To view a copy of this licence, visit http://creativecommons.org/licenses/by/4.0/.

\section{References}

Alberton B, Torres RDS, Cancian LF et al (2017) Introducing digital cameras to monitor plant phenology in the tropics: applications for conservation. Perspect Ecol Conserv 15:82-90. https://doi.org/10.1016/j. pecon.2017.06.004

Arend M, Kuster T, Günthardt-Goerg MS, Dobbertin M (2011) Provenance-specific growth responses to drought and air warming in three European oak species (Quercus robur, Q. petraea and $Q$. pubescens). Tree Physiol 31:287-297. https://doi.org/10.1093/treephys/tpr004

Badgley G, Field CB, Berry JA (2017) Canopy near-infrared reflectance and terrestrial photosynthesis. Sci Adv 3(3):e1602244. https://doi.org/10.1126/sciadv.1602244

Baresel JP, Rischbeck P, Hu Y et al (2017) Use of a digital camera as alternative method for non-destructive detection of the leaf chlorophyll content and the nitrogen nutrition status in wheat. Comput Electron Agric 140:25-33. https://doi.org/10.1016/j.compag.2017.05.032

Benedict HM, Swidler R (1961) Nondestructive method for estimating chlorophyll content of leaves. Science 133:2015-2016. https://doi.org/10.1126/science.133.3469.2015

Bert D, Lebourgeois F, Ponton S et al (2020) Which oak provenances for the 22nd century in Western Europe? Dendroclimatology in common gardens. PLoS ONE 15:e0234583

Biliouris D, Van der Zande D, Verstraeten WW et al (2009) Assessing the impact of canopy structure simplification in common multilayer models on irradiance absorption estimates of measured and virtually created Fagus sylvatica (L.) stands. Remote Sens 1:1009-1027. https://doi.org/10.3390/rs1041009

Blackburn GA (1998) Quantifying chlorophylls and caroteniods at leaf and canopy scales: an evaluation of some hyperspectral approaches. Remote Sens Environ 66:273-285. https://doi.org/10.1016/S00344257(98)00059-5

Chaves M, Maroco J, Pereira J (2003) Understanding plant responses to drought-from genes to the whole plant. Funct Plant Biol 30(3):239-264. https://doi.org/10.1071/FP02076

Chawade A, Van Ham J, Blomquist H et al (2019) High-throughput field-phenotyping tools for plant breeding and precision agriculture. Agronomy 9:1-18. https://doi.org/10.3390/agronomy9050258

Chianucci F, Ferrara C, Pollastrini M, Corona P (2019) Development of digital photographic approaches to assess leaf traits in broadleaf tree species. Ecol Ind 106:105547. https://doi.org/10.1016/j.ecolind. 2019.105547

Choat B, Brodribb TJ, Brodersen CR et al (2018) Triggers of tree mortality under drought. Nature 558:531539. https://doi.org/10.1038/s41586-018-0240-X

Chung S, Breshears LE, Yoon J-Y (2018) Smartphone near infrared monitoring of plant stress. Comput Electron Agric 154:93-98. https://doi.org/10.1016/j.compag.2018.08.046

Cocozza C, Paoletti E, Mrak T et al (2020) Isotopic and water relation responses to ozone and water stress in seedlings of three oak species with different adaptation strategies. Forests 11(8):864. https://doi.org/ 10.3390/f11080864

Coffin D (2018) Dave Coffin's raw photo decoder. https://www.dechifro.org/dcraw/dcraw.c, v. 9.28, dcraw.c

Cohen-Shacham E, Walters G, Janzen C, Maginnis S (2016) Nature-based solutions to address global societal challenges, vol 97. IUCN, Gland

Collet C, Frochot H (1996) Effects of interspecific competition periodic shoot elongation in oak seedlings. Can J For 26:1934-1942. https://doi.org/10.1139/x26-218

Colombo R, Busetto L, Meroni M, Rossini M, Panigada C (2012) Optical remote sensing of vegetation water content. In: Thenkabail PS, Lyon JG, Huete A (eds) Hyperspectral remote sensing of vegetation. CRC Press, Boca Raton, pp 227-239 
Combes D, Bousquet L, Jacquemoud S et al (2007) A new spectrogoniophotometer to measure leaf spectral and directional optical properties. Remote Sens Environ 109:107-117. https://doi.org/10.1016/j.rse. 2006.12.007

Cotrozzi L, Couture JJ (2019) Hyperspectral assessment of plant responses to multi-stress environments: prospects for managing protected agrosystems. Plants People Planet. https://doi.org/10.1002/ppp3. 10080

Cotrozzi L, Remorini D, Pellegrini E et al (2016) Variations in physiological and biochemical traits of oak seedlings grown under drought and ozone stress. Physiol Plant 157:69-84. https://doi.org/10.1111/ ppl.12402

Cotrozzi L, Couture JJ, Cavender-Bares J et al (2017) Using foliar spectral properties to assess the effects of drought on plant water potential. Tree Physiol 37:1582-1591. https://doi.org/10.1093/treephys/tpx 106

Cotrozzi L, Townsend PA, Pellegrini E et al (2018) Reflectance spectroscopy: a novel approach to better understand and monitor the impact of air pollution on Mediterranean plants. Environ Sci Pollut Res Int 25:8249-8267. https://doi.org/10.1007/s11356-017-9568-2

Croft H, Chen JM, Luo X et al (2017) Leaf chlorophyll content as a proxy for leaf photosynthetic capacity. Glob Change Biol 23:3513-3524. https://doi.org/10.1111/gcb.13599

Croft H, Chen JM, Wang R et al (2020) The global distribution of leaf chlorophyll content. Remote Sens Environ 236:111479. https://doi.org/10.1016/j.rse.2019.111479

Demmig-Adams B, Cohu CM, Muller O, Adams WW (2012) Modulation of photosynthetic energy conversion efficiency in nature: from seconds to seasons. Photosynth Res 113:75-88. https://doi.org/10. 1007/s11120-012-9761-6

Dey DC, Gardiner ES, Schweitzer CJ et al (2012) Underplanting to sustain future stocking of oak (Quercus) in temperate deciduous forests. New For 43:955-978. https://doi.org/10.1007/s11056-012-9330-z

Di Gennaro SF, Rizza F, Badeck FW et al (2018) UAV-based high-throughput phenotyping to discriminate barley vigour with visible and near-infrared vegetation indices. Int J Remote Sens 39:5330-5344. https://doi.org/10.1080/01431161.2017.1395974

do Amaral ES, Vieira Silva D, Dos Anjos L et al (2019) Relationships between reflectance and absorbance chlorophyll indices with RGB (Red, Green, Blue) image components in seedlings of tropical tree species at nursery stage. New For 50:377-388. https://doi.org/10.1007/s11056-018-9662-4

Ducousso A, Bordacs S (2004) EUFORGEN technical guidelines for genetic conservation and use for pedunculate and sessile oaks (Quercus robur and Q. petraea). International Plant Genetic Resources Institute, Rome

Dutta S, Cruz JA, Imran SM et al (2017) Variations in chloroplast movement and chlorophyll fluorescence among chloroplast division mutants under light stress. J Exp Bot 68:3541-3555. https://doi.org/10. 1093/jxb/erx203

Eckstein D, Künzel V, Schäfer L, Winges M (2019) Global climate risk index 2020. Germanwatch, Bonn

Esteban R, Barrutia O, Artetxe U et al (2015) Internal and external factors affecting photosynthetic pigment composition in plants: a meta-analytical approach. New Phytol 206:268-280. https://doi.org/10.1111/ nph. 13186

FAO (2013) Strategic framework on Mediterranean forests. Tlemcen, March 21, 2013. http://foris.fao.org/ meetings/download/_2017/xxii_session_of_the_committee_on_mediterranean_for/misc_documents/ sfmf_en.pdf

Fardusi MJ, Chianucci F, Barbati A (2017) Concept to practices of geospatial information tools to assist forest management and planning under precision forestry framework : a review. Ann Silvic Res 41(1):3-14

Féret J-B, Francois C, Asner G et al (2008) PROSPECT-4 and 5: advances in the leaf optical properties model separating photosynthetic pigments. Remote Sens Environ 112:3030-3043. https://doi.org/10. 1016/j.rse.2008.02.012

Féret J-B, Francois C, Gitelson A et al (2011) Optimizing spectral indices and chemometric analysis of leaf chemical properties using radiative transfer modeling. Remote Sens Environ 115:2742-2750. https:// doi.org/10.1016/j.rse.2011.06.016

Früchtenicht E, Neumann L, Klein N et al (2018) Response of Quercus robur and two potential climate change winners-Quercus pubescens and Quercus ilex - to two years summer drought in a semicontrolled competition study: I-tree water status. Environ Exp Bot 152:107-117. https://doi.org/10. 1016/j.envexpbot.2018.01.002

Fulcher A, LeBude AV, Owen JS et al (2016) The next ten years: strategic vision of water resources for nursery producers. HortTechnol 26:121-132. https://doi.org/10.21273/horttech.26.2.121

Gil-Pelegrín E, Saz MÁ, Cuadrat JM et al (2017) Oks under Mediterranean-type climates: functional response to summer aridity. In: Gil-Pelegrín E, Peguero-Pina JJ, Sancho-Knapik D (eds) Oaks 
physiological ecology exploring the functional diversity of genus Quercus L. Springer, New York, pp 137-193

Gitelson A, Merzlyak MN (1994) Spectral reflectance changes associated with autumn senescence of Aesculus hippocastanum L. and Acer platanoides L. leaves. Spectral features and relation to chlorophyll estimation. J Plant Physiol 143:286-292. https://doi.org/10.1016/S0176-1617(11)81633-0

Gitelson AA, Kaufman YJ, Merzlyak MN (1996) Use of a green channel in remote sensing of global vegetation from EOS-MODIS. Remote Sens Environ 58:289-298. https://doi.org/10.1016/S0034-4257(96) 00072-7

Granados M, Ajdin B, Wand M et al (2010) Optimal HDR reconstruction with linear digital cameras. In: 2010 IEEE computer society conference on computer vision and pattern recognition, pp 215-222. https://gvv.mpi-inf.mpg.de/projects/opthdr/granados10_opthdr.pdf

Green JK, Seneviratne SI, Berg AM et al (2019) Large influence of soil moisture on long-term terrestrial carbon uptake. Nature 565:476-479. https://doi.org/10.1038/s41586-018-0848-X

Gupta A, Rico-Medina A, Caño-Delgado A (2020) The physiology of plant responses to drought. Science 368:266-269. https://doi.org/10.1126/science.aaz7614

Harou J, Pulido-Velazquez M, Rosenberg D et al (2009) Hydro-economic models: concepts, design, applications, and future prospects. J Hydrol 375:627-643. https://doi.org/10.1016/j.jhydrol.2009.06.037

He Y, Yang J, Caspersen J, Jones T (2019) An operational workflow of deciduous-dominated forest species classification: crown delineation, gap elimination, and object-based classification. Remote Sens 11:1-23. https://doi.org/10.3390/rs11182078

Hoerling M, Eischeid J, Perlwitz J et al (2012) On the increased frequency of mediterranean drought. J Clim 25:2146-2161. https://doi.org/10.1175/JCLI-D-11-00296.1

Homolová L, Malenovský Z, Clevers JGPW et al (2013) Review of optical-based remote sensing for plant trait mapping. Ecol Complex 15:1-16. https://doi.org/10.1016/j.ecocom.2013.06.003

Hoshika Y, Moura B, Paoletti E (2018) Ozone risk assessment in three oak species as affected by soil water availability. Environ Sci Pollut Res 25:8125-8136. https://doi.org/10.1007/s11356-017-9786-7

Hosoi F, Umeyama S, Kuo K (2019) Estimating 3D chlorophyll content distribution of trees using an image fusion method between 2D camera and 3D portable scanning lidar. Remote Sens 11(18):2134. https:// doi.org/10.3390/rs11182134

Humplík JF, Lazár D, Husičková A, Spíchal L (2015) Automated phenotyping of plant shoots using imaging methods for analysis of plant stress responses-a review. Plant Methods 11(1):1-10

Iglhaut J, Cabo C, Puliti S et al (2019) Structure from motion photogrammetry in forestry: a review. Curr For Rep. https://doi.org/10.1007/s40725-019-00094-3

Immitzer M, Atzberger C, Koukal T (2012) Tree species classification with random forest using very high spatial resolution 8-band worldView-2 satellite data. Remote Sens 4:2661-2693. https://doi.org/10. 3390/rs4092661

IPCC (2014) Climate change 2014: synthesis report. Contribution of working groups I, II and III to the fifth assessment report of the intergovernmental panel on climate change. Geneva. https://www.ipcc.ch/ report/ar5/syr/

Jacquemoud S, Baret F (1990) PROSPECT: a model of leaf optical properties spectra. Remote Sens Environ 34:75-91. https://doi.org/10.1016/0034-4257(90)90100-Z

Jacquemoud S, Ustin S (2019) Leaf optical properties. Cambridge University Press, Cambridge

Keenan TF, Darby B, Felts E et al (2014) Tracking forest phenology and seasonal physiology using digital repeat photography: a critical assessment. Ecol Appl 24:1478-1489. https://doi.org/10.1890/ 13-0652.1

Knapp AK, Carter GA (1998) Variability in leaf optical properties among 26 species from a broad range of habitats. Am J Bot 85:940-946. https://doi.org/10.2307/2446360

Knight J, Abdi DE, Ingram DL, Fernandez RT (2019) Water scarcity footprint analysis of container-grown plants in a model research nursery as aected by irrigation and fertilization treatments. Water (Switzerland) 11(12):2436. https://doi.org/10.3390/W11122436

Knighton N, Bugbee B (2005) A mixture of barium sulfate and white paint is a low-cost substitute reflectance standard for spectralon®. Techniques and Instruments paper 11. https://digitalcommons.usu. edu/cpl_techniquesinstruments/11

Kuester MA (2016) Absolute radiometric calibration 2015v2: longmont. DigitalGlobe, Colorado

Lin C (2018) A novel effective chlorophyll indicator for forest monitoring using worldview-3 multispectral reflectance. In: IGARSS 2018-2018 IEEE international geoscience and remote sensing symposium, pp 5220-5223. https://doi.org/10.1109/IGARSS.2018.8518275

Lin C, Lin C (2019) Using ridge regression method to reduce estimation uncertainty in chlorophyll models based on worldview multispectral data. In: IGARSS 2019-2019 IEEE international geoscience and remote sensing symposium, pp 1777-1780. https://doi.org/10.1109/IGARSS.2019.8900593 
Lin CW, Tseng CM, Tseng YH et al (2013) Recognition of large scale deep-seated landslides in forest areas of Taiwan using high resolution topography. J Asian Earth Sci 62:389-400. https://doi.org/10.1016/j. jseaes.2012.10.022

Lobo A, Torres-Ruiz JM, Burlett R et al (2018) Assessing inter- and intraspecific variability of xylem vulnerability to embolism in oaks. For Ecol Manag 424:53-61. https://doi.org/10.1016/j.foreco.2018.04. 031

Löf M, Madsen P, Metslaid M et al (2019) Restoring forests: regeneration and ecosystem function for the future. New For 50:139-151. https://doi.org/10.1007/s11056-019-09713-0

Mahlein A-K, Kuska MT, Behmann J et al (2018) Hyperspectral sensors and imaging technologies in phytopathology: state of the art. Annu Rev Phytopathol 56:535-558

Majsztrik JC, Fernandez RT, Fisher PR et al (2017) Water use and treatment in container-grown specialty crop production: a review. Water Air Soil Pollut 228:151. https://doi.org/10.1007/s11270-017-3272-1

Mariotti B, Maltoni A, Jacobs DF, Tani A (2015) Container effects on growth and biomass allocation in Quercus robur and Juglans regia seedlings. Scand J For Res 30:401-415. https://doi.org/10.1080/ 02827581.2015.1023352

Mariotti B, Martini S, Raddi S et al (2019) Is it possible to produce forest nursery stock to face droughty periods after transplanting? In: Book of abstracts XXV IUFRO world congress forest research and cooperation, Pesq.flor. bras., vol 768, p 325. https://app.oxfordabstracts.com/events/691/program-app/ submission/95405

Mariotti B, Martini S, Raddi S et al (2020) Coconut coir as a sustainable nursery growing media for seedling production of the ecologically diverse quercus species. Forests 11:4-7. https://doi.org/10.3390/ F11050522

Marshall VM, Lewis M, Ostendorf B (2012) Buffel grass (Cenchrus ciliaris) as an invader and threat to biodiversity in arid environments: a review. J Arid Environ 78:1-12. https://doi.org/10.1016/j.jarid env.2011.11.005

McFeeters SK (1996) The use of the normalized difference water index (NDWI) in the delineation of open water features. Int J Remote Sens 17:1425-1432. https://doi.org/10.1080/01431169608948714

Mereu V, Santini M, Cervigni R et al (2018) Robust decision making for a climate-resilient development of the agricultural sector in Nigeria. In: Lipper L, McCarthy N, Zilberman D et al (eds) Climate smart agriculture: building resilience to climate change. Springer, Cham, pp 277-306

Méthy M, Damesin C, Rambal S (1996) Drought and photosystem II activity in two Mediterranean oaks. Ann Sci For 53:255-262. https://doi.org/10.1051/forest:19960208

Mölder A, Meyer P, Nagel R-V (2019) Integrative management to sustain biodiversity and ecological continuity in Central European temperate oak (Quercus robur, Q. petraea) forests: an overview. For Ecol Manag 437:324-339. https://doi.org/10.1016/j.foreco.2019.01.006

Nebiker S, Lack N, Abächerli M, Läderach S (2016) Light-weight multispectral UAV sensors and their capabilities for predicting grain yield and detecting plant diseases. Int Arch Photogramm Remote Sens Spatial Inf Sci 41:12-19. https://doi.org/10.5194/isprsarchives-XLI-B1-963-2016

Noctor G, Reichheld J-P, Foyer CH (2018) ROS-related redox regulation and signaling in plants. Semin Cell Dev Biol 80:3-12. https://doi.org/10.1016/j.semcdb.2017.07.013

Ollinger SV (2011) Sources of variability in canopy reflectance and the convergent properties of plants. New Phytol 189:375-394. https://doi.org/10.1111/j.1469-8137.2010.03536.x

Osakabe Y, Osakabe K, Shinozaki K, Tran L-SP (2014) Response of plants to water stress. Front Plant Sci 5:86. https://doi.org/10.3389/fpls.2014.00086

Ourcival JM, Joffre R, Rambal S (1999) Exploring the relationships between reflectance and anatomical and biochemical properties in Quercus ilex leaves. New Phytol 143:351-364. https://doi.org/10.1046/j. 1469-8137.1999.00456.x

Perez-Sanz F, Navarro PJ, Egea-Cortines M (2017) Plant phenomics: an overview of image acquisition technologies and image data analysis algorithms. GigaScience 6:1-18. https://doi.org/10.1093/gigas cience/gix092

Puletti N, Mattioli W, Bussotti F, Pollastrini M (2019) Monitoring the effects of extreme drought events on forest health by Sentinel-2 imagery. J Appl Remote Sens 13:1. https://doi.org/10.1117/1.jrs.13.020501

Putra WBT, Soni P (2017) Evaluating NIR-Red and NIR-Red edge external filters with digital cameras for assessing vegetation indices under different illumination. Infrared Phys Technol 81:148-156. https:// doi.org/10.1016/j.infrared.2017.01.007

R Development Core Team (2020) R: a language and environment for statistical computing. R Foundation for Statistical Computing, Vienna, Austria. http://www.r-project.org/index.html

Reiche J, Hamunyela E, Verbesselt J et al (2018) Improving near-real time deforestation monitoring in tropical dry forests by combining dense Sentinel-1 time series with Landsat and ALOS-2 PALSAR-2. Remote Sens Environ 2018:147-161. https://doi.org/10.1016/j.rse.2017.10.034 
Reyer CPO, Leuzinger S, Rammig A et al (2013) A plant's perspective of extremes: terrestrial plant responses to changing climatic variability. Glob Change Biol 19:75-89. https://doi.org/10.1111/gcb. 12023

Richardson AD, Hufkens K, Milliman T et al (2018) Tracking vegetation phenology across diverse North American biomes using PhenoCam imagery. Sci Data 5:1-24. https://doi.org/10.1038/sdata.2018.28

Ritchie GL (2007) Ground-based and aerial remote sensing methods for estimating cotton growth, water stress, and defoliation. Ph.D. Thesis, Utah State University. https://getd.libs.uga.edu/pdfs/ritchie_ glen_1_200708_phd.pdf

Rohatgi A (2017) WebPlotDigitizer. Version 4.0. https://automeris.io/WebPlotDigitizer/

Rouse JW, Haas RH, Schell JA, Deering DW (1973) Monitoring vegetation systems in the great plains with ERTS. In: NASA (ed) Third ERTS D.A. Symposium, NASA SP 351, Washington, DC, pp 309-317. Accessed by https://google.books.com

Salas-Aguilar V, Sánchez-Sánchez C, Rojas-García F et al (2017) Estimation of vegetation cover using digital photography in a regional survey of central Mexico. Forests 8:1-18. https://doi.org/10.3390/f8100 392

Schuldt B, Buras A, Arend M et al (2020) A first assessment of the impact of the extreme 2018 summer drought on Central European forests. Basic Appl Ecol 45:86-103. https://doi.org/10.1016/j.baae. 2020.04.003

Serrano L (2008) Effects of leaf structure on reflectance estimates of chlorophyll content. Int J Remote Sens 29:5265-5274. https://doi.org/10.1080/01431160802036359

Sibanda M, Mutanga O, Rouget M, Kumar L (2017) Estimating biomass of native grass grown under complex management treatments using worldview-3 spectral derivatives. Remote Sens 9(1):55. https:// doi.org/10.3390/rs9010055

Sims D, Gamon J (2002) Relationships between leaf pigment content and spectral reflectance across a wide range of species, leaf structures and developmental stages. Remote Sens Environ 81:337-354. https:// doi.org/10.1016/S0034-4257(02)00010-X

Sonobe R, Wang Q (2017) Towards a universal hyperspectral index to assess chlorophyll content in deciduous forests. Remote Sens 9(3):191. https://doi.org/10.3390/rs9030191

Thenkabail P, Lyon J, Huete A (2019) Fundamentals, sensor systems, spectral libraries, and data mining for vegetation. CRC Press, Boca Raton

Tognetti R, Longobucco A, Miglietta F, Raschi A (1998) Transpiration and stomatal behaviour of Quercus ilex plants during the summer in a Mediterranean carbon dioxide spring. Plant Cell Environ 21:613622. https://doi.org/10.1046/j.1365-3040.1998.00301.x

Trumbore S, Brando P, Hartmann H (2015) Forest health and global change. Science 349:814-818. https:// doi.org/10.1126/science.aac6759

Updike T, Comp C (2010) Radiometric Use of WorldView-2 Imagery. Technical Note, pp 1-17. https://dgcms-uploads-production.s3.amazonaws.com/uploads/document/file/104/Radiometric_Use_of_World View-2_Imagery.pdf

Ustin S, Jacquemoud S (2020) How the optical properties of leaves modify the absorption and scattering of energy and enhance leaf functionality. In: Cavender-Bares J, Gamon JA, Townsend PA (eds) Remote sensing of plant biodiversity. Springer, Cham, pp 349-384

Vallauri D, Aronson J, Dudley N, Vallejo R (2005) Monitoring and evaluating forest restoration success. In: Mansourian S, Vallauri D (eds) Forest restoration in landscapes. Springer, New York, pp 150-158

Von Bueren SK, Burkart A, Hueni A et al (2015) Deploying four optical UAV-based sensors over grassland: challenges and limitations. Biogeosciences 12:163-175. https://doi.org/10.5194/bg-12-163-2015

Wada M (2016) Chloroplast and nuclear photorelocation movements. Proc Jpn Acad Ser B 92:387-411. https://doi.org/10.2183/pjab.92.387

Weil G, Lensky IM, Resheff YS, Levin N (2017) Optimizing the timing of unmanned aerial vehicle image acquisition for applied mapping of woody vegetation species using feature selection. Remote Sens 9(11):1130. https://doi.org/10.3390/rs9111130

Wickham H, François R, Henry L, Müller K, RStudio (2021) dplyr: a grammar of data manipulation. R package Version 1.0.6. https://CRAN.R-project.org/package=dplyr

Wolf A.F. (2012) Using WorldView-2 Vis-NIR multispectral imagery to support land mapping and feature extraction using normalized difference index ratios. In: Shen SS, Lewis PE (eds) Algorithms and technologies for multispectral, hyperspectral, and ultraspectral imagery XVIII, vol 8390. International Society for Optics and Photonics, p 83900N. https://doi.org/10.1117/12.917717

Wong CYS, D'Odorico P, Arain MA, Ensminger I (2020) Tracking the phenology of photosynthesis using carotenoid-sensitive and near-infrared reflectance vegetation indices in a temperate evergreen and mixed deciduous forest. New Phytol 226:1682-1695. https://doi.org/10.1111/nph.16479 
Yang H, Yang X, Heskel M et al (2017) Seasonal variations of leaf and canopy properties tracked by ground-based NDVI imagery in a temperate forest. Sci Rep 7:1-10. https://doi.org/10.1038/ s41598-017-01260-y

Zhang L, Zhang H, Niu Y, Han W (2019) Mapping maize water stress based on UAV multispectral remote sensing. Remote Sens 11:605. https://doi.org/10.3390/rs11060605

Zhao M, Running S (2010) Drought-induced reduction in global terrestrial net primary production from 2000 through 2009. Science 329:940-943. https://doi.org/10.1126/science.1192666

Publisher's Note Springer Nature remains neutral with regard to jurisdictional claims in published maps and institutional affiliations.

\section{Authors and Affiliations}

\section{Sabrina Raddi ${ }^{1}$ (D) Francesca Giannetti ${ }^{1}$ (D) Sofia Martini ${ }^{1}$ (D) Fabio Farinella ${ }^{1}$ (D) Gherardo Chirici $^{1} \mathbb{D} \cdot$ Andrea Tani $^{1} \cdot$ Alberto Maltoni $^{1}$ (D) Barbara Mariotti ${ }^{1}$}

Sabrina Raddi

sabrina.raddi@unifi.it

Sofia Martini

sofia.martini@unifi.it

Fabio Farinella

fabiofarinella94@gmail.com

Gherardo Chirici

gherardo.chirici@unifi.it

Andrea Tani

andrea.tani@unifi.it

Alberto Maltoni

alberto.maltoni@unifi.it

Barbara Mariotti

barbara.mariotti@unifi.it

1 DAGRI Dipartimento di Scienze e Tecnologie dei Sistemi Agrari Alimentari e Forestali, Università degli Studi di Firenze, Via San Bonaventura, 13, 50145 Florence, Italy 